\title{
Okul-Aile İş Birliği: Azerbaycan'da Bir Durum Çalışması
}

\author{
Gulshan Alizada ${ }^{1}$, Mualla Bilgin-Aksu ${ }^{2}$ \\ ${ }^{1}$ Bağımsız Araştırmacı,Bakü, Azerbaycan,gulshanalizada.s@gmail.com \\ ${ }^{2}$ Akdeniz Üniversitesi Emekli Öğretim Üyesi, Antalya, Türkiye, muallaaksu@akdeniz.edu.tr
}

Sorumlu Yazar: Gulshan Alizada

Makale Türü: Araştırma Makalesi

Bilgilendirme: Bu çalışma, 05-07 aralık 2019 tarihlerinde düzenlenen XI. Uluslararası Eğitim Denetimi Kongresi’nde sözlü bildiri olarak sunulmuştur.

Kaynak Gösterimi: Alizada, G., \& Bilgin-Aksu, M. (2021). Okul-aile iş birliği: Azerbaycan'da bir durum çalışması. Ĕgitimde Kuram ve Uygulama, 17(2), 11-40. doi: 10.17244/eku.913704

Etik Not: Araştırma ve yayın etiğine uyulmuştur. Bu çalışmada veriler 2020 yılı öncesi toplanmış olup, veri toplama sürecinde katılımcıların gönüllü katılımı gözetilmiştir.

\section{School-Family Collaboration: A Case Study in Azerbaijan \\ Gulshan Alizada ${ }^{1}$, Mualla Bilgin-Aksu² \\ ${ }^{1}$ Independent Researcher, Baku, Azerbaijan,gulshanalizada.s@gmail.com \\ ${ }^{2}$ Akdeniz University Retired Professor,Antalya,Turkey, muallaaksu@akdeniz.edu.tr}

Corresponding Author: Gulshan Alizada

Article Type: Research Article

Acknowledgement: This study was presented as an oral paper in the "11th Educational Supervision International Conference" held on December 5th-7th, 2019.

To Cite This Article: Alizada, G., \& Bilgin-Aksu, M. (2021). Okul-aile iş birliği: Azerbaycan'da bir durum çalışması. Eğitimde Kuram ve Uygulama, 17(2), 11-40. doi: 10.17244/eku.913704

Ethical Note: Research and publication ethics were followed. In this study, the data were collected before 2020, and voluntary participation of study group was observed during the data collection period. 


\title{
Okul-Aile İş Birliği: Azerbaycan'da Bir Durum Çalışması
}

\author{
Gulshan Alizada ${ }^{1}$, Mualla Bilgin-Aksu² \\ ${ }^{1}$ Bă̆ımsız Araştırmacı, Bakü, Azerbaycan \\ gulshanalizada.s@gmail.com,ORCID:0000-0002-3850-1439 \\ ${ }_{2}^{2}$ Akdeniz Üniversitesi Emekli Ögretim Üyesi, Antalya, Türkiye \\ muallaaksu@akdeniz.edu.tr,ORCID:0000-0001-5304-4582
}

\begin{abstract}
Öz
Bu çalışmanın amacı, Azerbaycan'ın Bakü ilinde yer alan okullarındaki yönetici, öğretmen ve veli görüşlerine göre okul-aile iş birliğine ilişkin durumu belirlemektir. Bu amaçla Bakü ilinin sosyoekonomik açıdan farklı düzeye sahip ilçelerinde öğretim hizmeti veren üç ayrı okul seçilmiştir. Bu okullardan amaçlı ve ölçüt örnekleme yöntemleriyle seçilen üç yönetici, altı ögretmen ve 12 veli olmak üzere toplam 21 kişinin katılımıyla durum çalışması deseni uygulanmıştır. Veriler yüz yüze görüşme ve doküman incelemesi yoluyla toplanmıştır. Bulgular, çalışmanın amaçları doğrultusunda altı temada sunulmuştur: (1) Paydaşlardan beklenen sorumluluklar, (2) okul-aile iş birliği uygulamaları, (3) okul-aile iletişim yolları, (4) okul-aile iş birliği sorunları, (5) okul-aile iş birliği sorunlarının çözüm yolları ve (6) okul-aile iş birliğinin paydaşlara etkisi. Çalışmanın sonuçlarına göre, okul-aile iş birliğinde okuldan nitelikli eğitim-öğretim ortamı sağlama, velilerle iş birliğine açık olma, veliyi bilgilendirme; veliden çocuğunun eğitim-öğretimiyle ilgilenme, okuldaki öğretimi evde devam ettirme, okulla iletişimde olma, Mektepli Kitapçası'nı takip etme, veli toplantısına ve okul faaliyetine katılma beklenmektedir. Birlikte hareket etme ve eşit katkı sağlama ise paydaşların ortak sorumluluğu olarak belirlenmiştir. Okul-aile iş birliği uygulamaları arasında toplantı, seminer, "Velinin Okulda Bir Günü”, velilerin etkinliklere katılımını sağlama, bireysel görüşme ve velinin ders dinlemesi bulunmaktadır. Okul-aile iş birliği sürecinde iletişim için, Mektepli Kitapçası, telefon, WhatsApp grubu ve veli komitesi başkanından yararlanılmaktadır. Okulaile iş birliğinin temel sorunları, öğretmenin ayrımcılık yapması, öğrenciye bireysel yaklaşmaması, Mektepli Kitapçası'na değerlendirme notunu yazmaması ve ders yapmaması; velinin çocuğunun eğitim-öğretimiyle ilgilenmemesi, toplantılara katılmaması, yüksek not beklentisi; öğrencinin öğretim ortamını bölmesi, öğreniminde başarısız olması ve velisine yalan söylemesidir. İş birliği sorunları için, yüz yüze veya telefonla konuşmaya ve birlikte çözüm yolu aramaya çalışılmaktadır. Okul-aile iş birliği paydaşların mutluluğu, veli memnuniyeti ve öğrenci başarısını artırmaktadır.
\end{abstract}

\author{
Makale Bilgisi \\ Anahtar kelimeler: Okul-Aile \\ İş birliği, Okul Yöneticisi, \\ Öğretmen, Veli
}

\section{Makale Geçmişi:}

Geliş: 12 Nisan 2021

Düzeltme: 26 Mayıs 2021

Kabul: 8 Ağustos 2021

Makale Türü: Araştırma Makalesi 


\section{School-Family Collaboration: A Case Study in Azerbaijan}

\begin{abstract}
The aim of this study is to determine the situation regarding school-family collaboration according to the views of administrators, teachers, and parents in Baku/Azerbaijani schools. For the study conducted in case study design, three separate schools serving education were selected in the socioeconomically different districts of Baku province. The study data were collected through face-to-face interviews and document reviews and analysed with descriptive method. The findings are presented in six themes in line with the purposes of the research: (1) responsibilities expected from stakeholders, (2) school-family collaboration practices, (3) school-family communication ways, (4) school-family collaboration problems, (5) solutions to the problems of school-family collaboration, and (6) the impact of school-family collaboration on stakeholders. According to the results of the study expected responsibilities from the school in school-family collaboration are to provide a good educational environment, to be open to collaboration, to inform the parents. The expected responsibilities from the parents are to involve closely in the education of their children's education, to support school's training at home, to communicate with the school, to follow the Student Diary, participating at the school activities from the parents. On the other hand, acting together and making equal contribution are stated the stakeholders' common responsibilities. School-family collaboration practices include meetings, seminars, "Parents' Day at School", ensuring parents' participation in activities, individual parents meeting and parents' observation at the lesson. For the communication in the school-family collaboration process are benefitted from The Student Diary, telephone, WhatsApp groups and parent committee chairman. In schoolfamily collaboration, main problems caused by from the teachers are discrimination among students, not taking into account the student's individual needs, not writing evaluation notes in the "The School Diary" and neglecting their lessons; problems caused by the parents are not being involved in their child's education, not participating in the meetings, expecting higher points from the teacher; problems caused by the students are disrupting teaching environment, failing the class and lying to the parents. Collaboration problems are talked with face to face or by phone and they are tried to find solutions together. School-family collaboration increases the happiness of the stakeholders, parents' satisfaction, and student success.
\end{abstract}

\author{
Article Info \\ Keywords: Parent, School- \\ Family Collaboration, School \\ Principal, Teacher
}

\author{
Article History: \\ Received: 12 April 2021 \\ Revised: 26 May 2021 \\ Accepted: 8 August 2021
}

Article Type: Research Article 


\section{Extended Summary}

The relationship among teacher, student, and parent, which are the three basic elements of the educational process at school, can be likened to a trivet. Student success constitutes the centrepiece of the trivet. Success of the student depends on parents' support to education given at school. Such a support can only be achieved through a strong collaboration between the school and the family. School-family collaboration is the combination of the efforts and activities of parents and teachers to support the development of the child in a sense of mutual responsibility. School and family have mutual expectations regarding the education of children and young people who will become adults of the future, and schoolfamily collaboration plays an important role in meeting these expectations.

The purpose of this study conducted with a case study design of qualitative method is, to reveal the current situation of school-family collaboration in Baku/Azerbaijan based on the views of school administrators, teachers, and parents. To achieve this purpose, the following questions were searched for the answers: conducted with a case study design of qualitative method, is to reveal the current situation of school-family collaboration in Baku/Azerbaijan based on the views of school administrators, teachers and parents. To achieve this purpose, the following questions were searched:

1. What are the responsibilities expected from stakeholders in school-family collaboration?

2. What are school-family collaboration practices?

3. How is communication provided during the school-family collaboration process?

4. What are the problems encountered in the school-family collaboration process?

5. What are the ways to solve the problems encountered in the school-family collaboration process?

6. How does school-family collaboration affect stakeholders?

The study was carried out at schools in three districts, with different socioeconomic levels, of Baku, Azerbaijan in the 2019-2020 school year. These schools are determined in three categories as low, medium, and high in terms of the socioeconomic level of the society where the school is located. In the study group, there were total 21 voluntary participants consisting of one principal, two teachers, and four parents from each school. Data were collected through face-to-face interviews and document analysis and were analysed by descriptive method.

In line with the purposes of the study, six themes emerged from the views of the participants. These were named as expected responsibilities from the stakeholders, school-family collaboration practices, ways of communication in the school-family collaboration process, school-family collaboration problems, solutions to the problems of school-family collaboration and the impact of school-family collaboration on stakeholders.

In the theme of expected responsibilities of the stakeholders in school-family collaboration, three following categories were determined: (1) expected responsibilities from school, (2) expected responsibilities from parents, and (3) the school-parent partnership. The common views of all participants are to take care of the education and training of the child, to provide a good educational environment for the student, to be open to collaboration with parents and to act together as the school and the family.

The second theme involves the practices of school-family collaboration. According to the findings, the practices of school-family collaboration are organizing meetings, face-to-face individual meeting, ensuring parents' participation in school activities, Parents' Day at School (Open Door), organizing seminars, support of student's comrades, home visit, parents' observation at the lesson, giving a certificate of appreciation to parents, and psychological conversation and support.

Findings reveal that the ways of communication in the school-family collaboration are phone call, Student Diary, WhatsApp groups, bulletin boards, and informing parents through student and the chairman of parent committee. The most important communication way in the collaboration process is the phone for principals and teachers, but Student Diary for parents.

School-family collaboration problems were classified as problems caused by the school, problems caused by the parents, and problems caused by the student. Problems caused by the teachers are discrimination among students, not considering the student's individual needs, not writing evaluation notes in the "The School Diary" and neglecting their lessons; problems caused by the parents are not being involved in their child's education, not participating in the meetings, expecting higher points from the teacher; problems caused by the students are disrupting teaching environment, failing the class, and lying to the parents.

Participants' views regarding the solutions to the problems of school-family collaboration were classified under two categories as the school's solutions and the parents' solutions. The common views of the participants about solving school-family collaboration problems are face-to-face meeting, phone call, giving advice, informing parents, solving problems together, inviting parents to school and reprimanding the student. 
According to all participants, school-family collaboration creates a sense of happiness, parent satisfaction and increased student success. Principals and teachers indicated both negative and positive effects of school-family collaboration. According to them, negative effects are solving problems took time, desired results could not be reached when the support was not available, sense of exhaustion was experienced, school's reputation was damaged, and parents removed their child from school; while positive effects are increased school's reputation, feeling parents' support, and improved student behaviours. On the other hand, parents mentioned only positive effects of school-family collaboration such as socialization of parents and students.

As a result, although many practices aiming at providing more participation and awareness raising for the school-family collaboration are carried out at schools within study group, the collaboration process still needs improvement. Problems met by participating schools on school family collaboration process give rise to thought that the stakeholders do not fulfil their responsibilities enough. The fact that the participants mostly preferred to solve problems by talking face to face is consistent with the suggested behaviour as the best communication way in the literature. Results reveal that school-family collaboration creates both positive effects on all the stakeholders and negative effects on the administrators and teachers. Since it was conducted in a qualitative method, the study results, undoubtedly, cannot be generalized to all Azerbaijani schools. However, it is thought that the findings have the potential to raise awareness on the vital importance of school family collaboration not only for the schools in the study group but also for Azerbaijani education authorities. 


\section{Giriş}

Ulus ya da devletlerin gelişimi ve bağımsızlığının korunması için iyi yetişmiş bireylerden oluşan bir topluma gereksinim vardır. Bilindiği gibi insan yetiştirme, büyük bir çaba ve emek gerektiren bir süreçtir. Çocuğun ilk öğretmenleri ana babalardır ve onların eğitim görevleri okulun kapısında sona ermemektedir. Bu nedenle eğitim sürecinin ortakları olarak görev ve sorumluluklarının devam etmesi beklenmektedir. Aileler ayrıca çocuklarının zararlı alışkanlıkları olan arkadaş çevresi, kullanım düzeyi kontrol altında tutulamayan sosyal medya, sanal oyunlar ve yaşam koşullarının olumsuzluğu ile de başa çıkmak zorunda kalabilmektedir (Oskay, 1990; Goodman, 2015; Şahin \& Üstüner, 2018; Topçu, 2018). Çocukları günümüz koşullarının olumsuz etkisinden koruma isteği okul ve veli iş birliğini önemli kılmaktadır. Okul ile ailenin iş birliği yapması halinde çocuğun çok yönlü tanınarak gizilgücünün ortaya çıkarılması ve geliştirmesine katkı sağlamak, karşılaşılan sorunların çözümünde güç birliği yapmak, böylece çocuğun yararını en üst düzeye çıkarmak mümkündür. Ancak bu konuya ilişkin ulaşılabilen haber ve araştırmalardan elde edilen, okulun velilerle iş birliğine açik olmaması (Porsuk \& Kunt, 2012), okulda öğrencinin akran zorbalığına maruz kalması (İbrahimova, 2019), öğretmenin öğrenciye sözel ve fiziksel şiddet uygulaması (Gündüz M. , 2015), velinin okula gelip öğretmenlere şiddet uygulaması (Atmaca \& Öntaş, 2014), velinin çocuğuyla ilgilenmemesi (Porsuk \& Kunt, 2012), velinin okulla iş birliği yapmada duyarsız olması (Kulak, 2020) gibi bulgular, uygulamada beklentilerin yeterince karşılanmadığını göstermektedir. Diğer taraftan, okul-aile iş birliği konusunda eğitimcilerde farkındalık oluşturabilecek alan araştırmalarına Azerbaycan'da rastlanmamaktadır. Azerbaycan okullarında okul yöneticileri, öğretmenler ve velilerin yanı sıra, sistemin tüm paydaşlarının iş birliği çabasına katılmasında yarar görülmektedir.

Okulda eğitim-öğretim sürecinin üç temel öğesi olan öğretmen, öğrenci ve veli arasındaki ilişki bir sacayağına benzetilebilir. Sacayağının merkezini de öğrenci başarısı oluşturmaktadır (Bayar \& Bolat, 2020). Öğrencinin başarılı olması, okulda başlanan eğitim ve öğretimin evde de devam etmesi ve desteklenmesine bağlıdır (Hornby, 2011). Böyle bir destek, ancak okul ve aile arasındaki güçlü iş birliği ile sağlanabilir. İş birliği, insanların başarıya ulaşmak için amaç ve kararlar doğrultusunda güçlerini birleştirerek birlikte hareket etmeleri anlamına gelmektedir. Okul-aile iş birliği de veliler ve öğretmenlerin ortak sorumluluk anlayışı içinde öğrencinin gelişimini desteklemek amacıyla gösterdikleri çaba ve yaptıkları etkinliklerin birleşimi olarak tanımlanabilir. Burada eğitimin ve bir eğitim kurumu olarak okulun sosyal, ekonomik, siyasal ve bireyi geliştirme görevleri akla gelmektedir. Okullar bir yandan öğrencilerini toplumsallaştırarak sosyal görevlerini yerine getirirlerken, diğer yandan nitelikli vatandaş ve geleceğin liderlerini yetiştirerek siyasal işlevde bulunurlar. Azerbaycan Anayasası (1995) da vatandaşların sorumluluk sahibi, eşitlikçi, sosyal adaletçi, katılımcı, farklılıklara saygılı ve demokratik davranış biçimini içselleştirmiş olarak yetiştirilmesini öngörmektedir.

Geleceğin yetişkinleri olacak çocuk ve gençlerin eğitimi konusunda okul ile ailenin karşılıklı beklentileri vardır ve okul-aile iş birliği bu beklentilerin yerine getirilmesinde önemli bir role sahiptir. Velilerle okul arasında iş birliği oluşturmak için belirli koşulların sağlanması gerekir. Bu koşulların sağlanmasında da her bir paydaşın yerine getirmesi gereken sorumluluklar vardır. Başarılı bir iş birliği, iyi niyet, açıklık, saygı, sempati, dürüstlük ve takdir gibi özellikler içerir. İlişki kurma sürecinde, karşılıklı anlayış ve iş birliği için açık kurallar belirleme adımları önemlidir. Alanyazında, iş birliğinin oluşmasında gerek okul gerekse velinin sorumluluklarına ilişkin bulgulara rastlanılmaktadır. Polonya'da okul-veli iş birliği rehberi olarak hazırlanan kitapta, etkili bir iş birliği için öğretmenlerin ilk adımı atması, veliyle iletişime hazır olması, tüm velileri iş birliğine dâhil etmesi, velileri dinlemesi, eleştirilere ve yeni fikirlere açık olması, gereksinimler ve beklentiler hakkında net ve kararlı bir şekilde konuşması, öğrencileri aile ortamlarında tanıması, öğrencinin gelişimini sürekli izleyerek ana babayı bilgilendirmesi, ana babaya kötü haberi vermeden önce çocuğunun olumlu niteliklerinden bahsetmesi ve sorunlarla başa çıkmak için yardımcı olması okulun sorumluluğu olarak sunulmuştur (Lifelong Learning Programme, 2020). Bilgen'in (2019) çalışmasında ise, çocuğuna temizlik ve düzen alışkanlığı kazandırmak, beslenmesini ve sağlık hizmetlerinden yararlanmasını sağlamak, ders araç gereçlerini temin etmek, okul formasını almak, duygusal ilgi göstermek ve iletişim için kaliteli zaman ayırmak, sorunlarını paylaşmak, okula gittiğinden emin olmak, okulda ne yaptıklarını sormak, öğretmenle sürekli iletişim halinde olmak, ödevlerini izlemek ve gerektiğinde yardım etmek, öğretmen ve okulla iş birliği yapmak, okuldaki toplantılara katılmak, çocuğu sosyalleştirmek, sorumluluk kazanmasını sağlamak, sosyal etkinliklere yönlendirmek ve yaptıklarını izlemek veli sorumluluğu olarak belirlenmiştir.

Okulu ile veliyi birbirine yaklaştıracak uygulamalar ve taraflar arasındaki sağlıklı iletişim okul-aile iş birliğini pekiştirmektedir. Öğretmenlerin velilerle bireysel ve telefon görüşmeleri yapması, veli toplantıları ve haftalık görüşme saatleri düzenlemesi, öğrencinin defterine not yazması, veliyi okula davet etmesi, ev ziyaretleri ve sınıf eğlenceleri gibi etkinlikler gerçekleştirmesi okul-aile iş birliği kapsamında gerçekleştirilen önemli uygulamalardır (Yıldırım \& Dönmez, 2008). Filipinler'de Laguna eyaletinin Calamba şehrinde yürütülen bir çalışmada, velilerle sürekli iletişim halinde olarak öğrencinin akademik başarı durumu hakkında karşılıklı bilgi alışverişinde bulunmak için velilerle her dönemde en az iki kez görüşülmesi ve toplantı programlanması; herhangi bir olumsuz sonuçla karşılaşmamak için çocuğun derste olmadığına dair veliye bilgi iletilmesi; öğrenci yanlış davranışlar sergilediğinde bu sorunun aileden mi, arkadaş 
çevresinden mi veya okuldan mı kaynaklandığını saptamak amacıyla ev ziyaretleri yapılması; velileri çocuğunun akademik ve psikolojik gelişimi, çocuğuyla nasıl iletişim kuracağı ve çocuğuyla ilgili sorunları nasıl çözeceği konusunda bilinçlendirmek için bilgilendirme seminerleri ve atölye çalışmaları düzenlenmesi, okul-aile iş birliği kapsamındaki uygulamalar olarak ortaya çıkmıştır (Llamas \& Tuazon, 2016). Etnik kökeni farklı veliler ile odak grup görüşmesi yapan Baker'ın (1997) çalışmasında da velilerin okul gezilerine yardımcı olması; belli bir sorunu tartışmak için düzenlenmiş toplantılarda, açık kapı ve yardımlaşma yemeğinde yer alması; çocuğun ilerlemesi konusunda öğretmenle bireysel olarak ya da telefonla görüşmesi; çocuklarının gösteri ve müzikal performanslarını izlemek için okul etkinliklerine katılması uygulamalarının, velilerin hem kendilerinin hem de çocuklarının sosyalleşmesi ve çocuklarının eğitim-öğretim durumuna katkı sağlaması bakımından önemli gördükleri bulgusuna ulaşılmıştır. Okul-veli iş birliği sürecinde taraflar arasındaki iletişim kopukluğunu önleyecek bülten, mektup veya notlar, yazılı mesajlar, okulun web sitesi, ev ödevi günlüğü (Hornby \& Witte, 2010; Delgado-Gaitan, 1991), elektronik öğrenci kitapçığ1 (Abreu, Rocha, \& Cota, 2015) kullanılan önemli iletişim araçları olarak görülmektedir.

Kuşkusuz, her alanda olduğu gibi, okul-aile iş birliğinde de sorunlarla karşılaşılabilir. Bu konuda yapılan taramada farklı sorunların yaşandığına dair bulgular gözlenmiştir. Bulgular, okul-aile iş birliği alanında yaşanan sorunların tarafların kendi üzerlerine düşen sorumlulukları yerine getirmemelerinden kaynaklandığını göstermektedir. Okul yöneticilerinin etkinlikler konusunda velileri bilgilendirmeye önem vermemesi (Atayeter, 2004); öğretmenin öğrenci ve veliye eleştirel, sert, ilgisiz tavır sergilemesi ve veli toplantılarında maddi konulara yer verilmesi (Yıldırım \& Dönmez, 2008), okulun iletişime açık olmaması ve kendilerini uzman olarak gören öğretmenlerin başka fikir ve görüşleri dikkate almaması (Lawson, 2003), veli bir sorunu iletmek ve tartışmak için geldiğinde okul tarafından hoş karşılanmaması (Baker, 1997) okulun sorumluluklarını yerine getirmediğinin göstergeleridir. Okulla iş birliğine açık olmama, öğretmene yeterince güvenmeme, öğretmeni yöneticiye şikâyet etme, ihtiyaç duyulduğunda değil yalnız parasal problemlerde okula gelme, eğitim düzeyinin düşüklüğü, çocuğuyla ilgilenmeme, çocuğun olumsuz davranışlarında okulu sorumlu tutma, çocuk eğitimindeki yetersizliği, başarı konusunda ödüllendirmek yerine cezaya başvurma, fazla otoriter davranma, öğretmenden çocukla ilgili fikir ve öneri almama, okul öğretim programı ve öğretmen hakkında yeterli bilgiye sahip olmama (Gül, 2007), okulla yeterince iş birliği yapmama, çocuklarını koruma amaçlı içgüdüsel davranışlar sergileme, öğretmen çalışmalarına fazla müdahale etme (Ünal, Yıldırım, \& Çelik, 2010) de yapılan çalışmalarda görülen veli kaynaklı sorunlardır.

Okul-aile iş birliğinde paydaşların her birinden kaynaklanan sorunlar yaşanırken paydaşların bu sorunların üstesinden nasıl geldiği de iş birliğini sağlıklı bir şekilde sürdürme açısından dikkat çeken bir konudur. Bazen ikna edilmesi veya sağlıklı iletişim kurulması zor velilerle karşılaşılmaktadır. Böyle bir durumda Tingley'in (tarih yok) şu önerilerini dikkate almak yararlı olabilir: (1) Velilerle herhangi bir sorun yaşamamak için öncelikle veliyi çocuğunun eğitim-öğrenim durumuyla ilgili sürekli bilgilendirmek ve bu amaçla gönderilmiş e-postaların, yapılmış telefon görüşmelerinin veya diğer konuşmaların kaydını tutmak. (2) Sorunu çözerken veliyle yüz yüze görüşmek, görüşme zamanı veliyi dinlemek ve gerektiğinde soru sormak, soruna ilişkin kanıtlar paylaşmak, üzerinde anlaşılabilecek ortak noktalar bulmaya çalışmak ve olumlu sonuca varılamadığında yöneticiyi bilgilendirmek. Sorunların çözümü için, Meador (2019) da Tingley gibi zor bir durum ortaya çıkmadan önce veliyle iletişim kurmayı, iyi bir dinleyici olmayı, söylediği her şeyi dikkate almayı, eğer veli çok sinirliyse sakinleştikten sonra konuşmayı sürdürmeyi ve eğer durum kontrolden çıkmışsa veliyi yöneticiye yönlendirmeyi önermiştir. Velileri okul politikası, okula zamanında ve devamlı gelme konusunda bilgilendirme, okula devamlı gelme konusunda oluşan soruları cevaplamak için okulda irtibat kurulaçak kişinin adını ve telefon numarasının verme, karşılıklı iletişimi sağlamak için iki yönlü iletişim kanalları oluşturma, devamlılık durumu iyileştirilmiş öğrencileri ödüllendirme, ev ziyaretleri yapma, devamsızlık sorunu kronik hal almış öğrenciler hakkında danışmanları ve ilgili memurları bilgilendirme okullarda yaşanan öğrenci devamsızlığı sorununu çözmek için önerilen yollardır (Epstein, 2015).

Okul-veli arasında sağlıklı bir iş birliğinin olması, öğrencilerin eğitim-öğretimdeki başarılarını ve nitelikli bir birey olarak yetişmelerini olumlu yönde etkileyebilir. İncelenen çalışmalarda saptanan bulgular da bu görüşü destekler niteliktedir. Öğretmen ve yöneticiler veliyi çocuğunun eğitimine çekmeye kararlı olduklarında, öğrencinin akademik sonuçları olumlu yönde etkilenmektedir (Khajehpoura \& Ghazvini, 2011). Öğrencilerin okul, aile ve toplum tarafından desteklenmesi sonucunda öğrenci performansının artmasıyla birlikte önemli ölçüde kendilerini güvende olduklarını ve öndemsendiklerini hisseder, eğitimin hedeflerini anlar, tam potansiyellerine ulaşmak için çalışır, okula karş1 tutumları değişir, olumlu tutumlar ve okul davranışları sergiler, okul faaliyetlerine daha iyi katılım sağlar ve daha iyi sosyal beceriler kazanırlar (Epstein, et al., 2002; Epstein, 2015). Okul-aile iş birliği öğrencilerin akademik başarısını yükseltmenin yanı sıra, öğrencilerde öz farkındalık, daha iyi tutum ve gelişmiş kişisel nitelikler yaratmaktadır (Llamas \& Tuazon, 2016). Okul tarafından velilere katılımın türleri konusunda yeterli eğitim ve teşvik verildiği takdirde, ana babalar çocukların okuldaki öğrenme etkinliklerine olumlu katkı sağlayabilmektedir (Vahedi, 2010). Veliler, iş birliği sürecinde ana babalık, çocuk ve ergen gelişimi, evde çocuğun öğrenmesini desteklerken karşılaşılan güçlükler, okul 
program ve politikaları hakkında daha derin bilgi ve farkındalık kazanmışlardır (Llamas \& Tuazon, 2016). Velilerin okulla iş birliği yapması öğrenci başarısını artırmakla birlikte öğretmenlerin de sınıflarında daha etkili olmalarına yardımcı olmaktadır (Mewezino, 2010). Okul veli iş birliğinin oluşturulması sonucunda okul programları ve okul iklimi iyileştirebilir, aile hizmetleri ve desteği sağlanabilir, velilerin becerileri ve liderliği artırılabilir, ailelerin okuldaki ve toplumdaki diğer kişilerle iletişimi kurulabilir ve öğretmenlere çalışmalarında yardımcı olunabilir (Epstein, et al., 2002). Yapılan çalışmalar okul-aile iş birliğinin sadece öğrenciler değil, veliler ve öğretmenler üzerinde de olumlu etkiye sahip olduğunu ortaya koymaktadır.

Azerbaycan'da okul-aile iş birliği sürecinde velileri pedagojik olarak eğitmek, ailelerin okulla bağlantısını sağlamak, öğretmenlere genç neslin eğitim ve öğretiminde yardımcı olmak açısından veli komitesi önemli role sahiptir. Okullarda okul-aile iş birliğini sağlamak amacıyla okul ve sınıf veli komiteleri oluşturulmaktadır. Okul veli komitesi, eğitim-öğretim konularında okula yardımcı olma, velilerin okul faaliyetlerine aktif katılımını sağlama, okulun maddi kaynaklarının güçlendirilmesine yardım etme, çocukların ailedeki yaşam koşulları konusunu tartışma, önemli durumlarda velileri toplantıya davet etme, pedagojik ve psikolojik bilginin öğrenciler ve veliler arasında duyurulmasını sağlama gibi sorumluluklara sahiptir (Dünyamalıyeva, 2017). Ayrıca okul veli komitesi, okul faaliyetlerine yardımc1 olunması konusunda okul yönetimi ile birlikte ilgili kuruluşlara başvuru yapma, okul faaliyetinin iyileştirilmesi için önerilerde bulunma, çocuklarının eğitim-öğretimine katkısından dolayı velileri ödüllendirme, çocuklarının yetiştirilmesine kayıtsız kalan veliler üzerinde sosyal etki yaratma ve böyle velilerin iş yerlerinin yönetimini ve kamu kurumlarını bilgilendirme gibi haklara sahiptir (Dünyamalıyeva, 2017). Bu kadar önemli hak ve sorumluluklara sahip olan veli komitesi hakkında medyada karşılaşılan haberler, veli komite başkanlarının bu hak ve sorumluluklarla ilgili bilgiye sahip olmadığını ortaya koymaktadır. Yapılan haberlerden veli komite başkanlarının okullarda öğrencilerin eğitim-öğretim konularına odaklanmak yerine, sınıftaki öğrenciler için bayram şenliği düzenleme, öğretmenler gününde öğretmenlere hediyeler alma veya belli konularla ilgili para toplama gibi işlerle uğraştığı anlaşılmıştır (Raufquzı, 2015; Nəbiyeva, 2019).

Farklı ülkelerde yürütülmüş çalışmalarda okul-aile iş birliğinin önemi, paydaşların taşımaları gereken sorumluluklar, iş birliği sürecinde gerçekleştirilen uygulamalar ve yaşanan sorunlar, paydaşlar arasında iletişimin sağlanması, sorunların çözüm yolları ve iş birliğinin paydaşlara etkisine ilişkin birtakım bulgular ortaya konmuştur. Azerbaycan'da ise, okul-aile iş birliği konusunda herhangi bir alan araştırmasına ulaşılamamıştır. Bu durum böyle bir çalışmanın yapılması ihtiyacını açıkça ortaya koymuştur. Paydaşların iş birliği konusundaki sorumlulukları, bu süreçte gerçekleştirilen uygulamalar, kullanılan iletişim yolları, karşılaşılan sorunlar, sorunların nasıl çözüldüğü ve iş birliğinin paydaşları nasıl etkilediğinin Azerbaycan'ın Bakü ilindeki üç okuldan seçilen yönetici, sınıf rehber öğretmeni ve velilerin görüssleriyle belirlendiği bu çalışmada ulaşılan sonuçlardan eğitim sisteminin tüm paydaşlarının yararlanması beklenmektedir. Çalışma ayrıca alanyazında gözlenen boşluğu da doldurma gizilgücüne sahiptir.

\section{Çalışmanın Amacı}

Bu çalışmanın amacı, okul yöneticilerinin, öğretmen ve velilerin görüşlerine göre Bakü'de/Azerbaycan'da okul-aile iş birliğine ilişkin durumu ortaya koymaktır. Bu amaca ulaşmak için aşağıdaki sorulara yanıt aranmıştır:

1. Okul-aile iş birliğinde paydaşlardan beklenen sorumluluklar nelerdir?

2. Okul-aile iş birliği uygulamaları nelerdir?

3. Okul-aile iş birliği sürecinde iletişim nasıl sağlanmaktadır?

4. Okul-aile iş birliği sürecinde karşılaşılan sorunlar nelerdir?

5. Okul-aile iş birliği sürecinde karşılaşılan sorunların çözümünde kullanılan yollar nelerdir?

6. Okul-aile iş birliği paydaşları nasıl etkilemektedir?

\section{Yöntem}

Çalışma nitel yöntemin benimsendiği durum deseninde yürütülmüş̧ür. Tek bir veri kaynağı yerine doğal ortamında katılımcılarla yüz yüze etkileşime girerek, davranışları gözlemleyerek ve belgeleri inceleyerek veri toplama, verileri aşağıdan yukarıya doğru (kalıp, kategori, tema) analiz etme, birden çok bakış açısını rapor etme, öğrenilen duruma ilişkin birçok faktör belirleme, daha büyük resmin taslağını ortaya çıkarma açısından nitel yöntem araştırmacılar tarafından tercih edilmektedir (Creswell \& Creswell, 2014). Durum deseninde yapılan çalışmalarda vakanın özelliği ve karmaşıklığı derinine incelenerek araştırılmaktadır (Stake, 1995). Çalışmada, bu özellikler dikkate alınarak Bakü/Azerbaycan okullarında okul-aile iş birliği detaylı bir şekilde incelenmeye çalışılmıştır.

$\mathrm{Bu}$ çalışmada araştırma ve yayın etiğine uyulmuştur. Çalışmanın verileri 2020 yılı öncesi toplanmış olup, veri toplama sürecinde katılımcıların gönüllü katılımı gözetilmiştir. 


\section{Çalışma Grubu}

Çalışma, 2019 yılının haziran ve eylül aylarında ${ }^{1}$ Azerbaycan'ın Bakü ilinin sosyoekonomik açıdan düşük, orta ve yüksek düzeye sahip ilçelerindeki üç okulda yürütülmüş̧ür. Çalışmanın yürütüldüğü üç okul müdüründen, bir kıdemli ve bir de az kıdemli sınıf rehber öğretmenin ismi istenmiştir. Ön görüşmede kendilerine çalışmanın amacı anlatılan tüm sınıf rehber öğretmenleri gönüllü katılım sağlamışlardır. Sonra ise her sınıf rehber öğretmeninden okul-aile iş birliğine bir aktif ve bir pasif katılım sergileyen veli belirlemeleri istenmiştir. Böylece çalışma grubu, üç yönetici, altı sınıf rehber öğretmen ve 12 veli olmak üzere toplam 21 kişiden oluşturulmuştur. Daha zengin veri elde etmek için, çalışmanın sosyoekonomik açıdan farklı düzeydeki ilçelerde eğitim-öğretim hizmeti veren okullarda yürütülmesi ve farklı katılımcı grubunun seçilmesi öngörülmüştür. Çalışma grubunun belirlenmesi amaçlı örnekleme yöntemiyle yapılmıştır. Amaçlı örneklemede de maksimum çeşitlilik ve ölçüt örnekleme uygulanmıştır. Maksimum çeşitlilik üç ayrı ilçeden, üç ayrı paydaş temsili ile sağlanırken; ölçütler öğretmenler için kıdem, veliler için de aktif ve pasif katılım olarak belirlenmiştir. Çalışma grubunu belirlerken amaçlı örneklemenin maksimum çeşitlilik yöntemini kullanmakta amaç, küçük bir örneklem oluşturarak bu örneklemde çalışılan probleme ilişkin görüş̧te bulunabilecek bireylerin çeşitliliğini maksimum derecede yansıtmaktır. Ölçüt örneklemeni kullanmakta amaç ise önceden belirlenmiş bir dizi ölçütü karşllayabilecek bütün durumları çalışmaktır (Yıldırım \& Şimşek, 2009).

Çalışma süresince gizlilik esaslarına bağlı kalınmış ve çalışma grubunda yer alan katılımcıların ismi kodlanarak verilmiștir. Kodlamada kullanılan ilk karakter, çalışma yapılan okulun bulunduğu ilçenin sosyoekonomik düzeyini (Yüksek: Y, Orta: O ve Düşük: D) göstermektedir. İkinci karakter, çalışma grubunun unvanını (Yönetici: Y, Öğretmen: Ö ve Veli: V), üçüncü karakter ise katılımcı olarak sırasını göstermektedir. Çalışma grubuna seçilen okullar da YD (Yüksek Düzey), OD (Orta Düzey) ve DD (Düşük Düzey) olarak kodlanmıştır.

\section{Veri Toplama Araçları}

Çalışmada iki tür veri toplama aracı kullanılmıştır. Katılımcıların okul-aile iş birliğine ilişkin görüşlerini belirlemek için yarı yapılandırılmış bir görüşme formu kullanılmıştır. Araştırmacılar tarafından okul-aile iş birliği konusunda yapılmış çalışmalar incelenerek kolay anlaşılabilecek, konu odaklı ve açık uçlu sorulara dayalı olan taslak form oluşturulmuştur. Bakü ilinden bir öğretmen ve bir veliyle çevrim içi olarak görüşüldükten sonra gerekli görülen düzenlemeler yapılarak araca son şekli verilmiştir. 2019'un haziran ayında sosyoekonomik açıdan orta ve düşük düzeye sahip ilçelerdeki toplam iki okulda, 2019'un Eylül ayında ise sosyoekonomik açıdan yüksek düzeye sahip ilçedeki okulda katılımcılarla görüşülmüş̧ür. Veri toplama işlemine başlamadan önce, katılımcılara araştırmacının görüşme nedeni, yapılan çalışmanın niteliği, katılımın gönüllülüğge dayandığı ve istediği an görüşmeden ayrılma hakkına sahip olduğu bilgisi verilmiş ve bu bilgilerin yazılı olduğu belgeyi imzalamaları istenmiştir. Katılımcılardan yazılı izin alınarak görüşmelerin ses kayıtları yapılmış, anlaşılmayan sorularda açıklamalarda bulunulmuş, daha zengin veri sağlamak amacıyla sondaj soruları sorulmuş ve sorunun amacı dışına çıkıldığı durumlarda müdahale edilmiştir. Görüşme sürecinde bazı katılımcılar, özellikle okul-aile iş birliği uygulamalarıyla ilgili soruya yanıt verirken iş birliği sürecinde iletişimin nasıl sağlandığı konusundaki görüşlerini de paylaşmışlardır. Görüşme formunda iletişimin nasıl sağlandığı sorusu ayrıca yer almakla birlikte katılımcıya herhangi bir müdahalede bulunulmamış, akışa göre gerekli değişikliler yapılmıştır. Altı açık uçlu sorudan oluşan görüşme formu aracıllğıyla, yaklaşı 34 dakika yönetici, 35 dakika öğretmen, 19 dakika veli ile olmak üzere toplam 9 saat 12 dakika yüz yüze görüşme yapılmışıır. Doküman analizi sürecinde ise, çalışmanın yürütüldüğü üç okulun resmî web sitesi ve sosyal medya sayfası incelenerek 2019 yılına ait okul-veli iş birliği konusundaki görsel içerikli haber ve paylaşımlar değerlendirilmiştir.

\section{Veri Analizi}

Yarı yapılandırılmış görüşme sonucunda elde edilmiş verilerin çözümlenmesinde içerik analizi kullanılmıştır. İçerik analizini kullanmakta amaç, okul-aile iş birliğine ilişkin elde edilmiş verileri tanımlamak ve verilerin altında yatan kavramları ortaya çıkarmaktır (Yıldırım \& Şimşek, 2009). Çalışmanın veri analizi sürecinde Çelik, Baykal ve Kılıç Memur'un (2020) nitel veri analizi konulu çalışmasından yararlanılmıştır. Verileri analiz etmek amacıyla öncelikle görüşme sürecinde elde edilen ses kayıtları deşifre edilerek bilgisayar ortamına aktarılmıştır. Ardından anlam bütünlüğü korunarak katılımcı ifadeleri üzerinde kodlamalar yapılmıştır. Yapılmış kodlamaların tümdengelim ve tümevarım analizi sonucunda altı ana tema elde edilmiştir. Bazı durumlarda kodlamaların sınıflandırılması sonucunda ana temaların altında da kategorilerin var olduğu saptanmıştır. Veriler analiz edilirken elde edilmiş temalar, kategoriler ve kodlara ilişkin yorumlarda bulunulmuş ve yorumlar, katılımcı görüşlerinden doğrudan alıntılarla desteklenmiştir.

\section{İnandırıcılık ve Aktarılabilirlik}

Çalışmanın inandırıcılık ve aktrılabilirliğini temin etmek için için aşağıdaki önlemler alınmıştır:

a) Çalışmanın inandırıcılığını sağlamak amacıyla görüşme formu tasarlanırken okul-veli iş birliğiyle ilgili farklı ülkelerde yürütülmüş çalışmalar incelenerek bir kavramsal çerçeve oluşturulmuştur. Görüşme sürecinde katıllımcılarla araştırmacı arasında güvenin oluşması ve katılımcıların geliştirilmiş görüşme formunun sorularına samimi cevap vermesi için öncelikle araştırmacı her bir katılımcıya kendisini tanıtmış, görüş̧me nedeninin okul-aile iş birliği konusunda bilimsel bir çalışma yapmak olduğunu açıklamış, çalışmaya gönüllü olarak katılıp katılmadığını sormuş, çalışmadan istediği an bir gerekçe söylemeden ayrılabileceğini söylemiş, çalışmada belirttiği görüşler dışında kimliğini ortaya çıkaracak herhangi bir bilgiye yer verilmeyeceğini, aksi yapıldığı takdirde mahkemede dava açma hakları bulunduğunu belirtmiştir. Katılımcı dürüstlüğünü destekleyen bu adımların atılması görüş̧e sürecinin samimi bir biçimde geçmesini temin etmiştir. Ayrıca yüz yüze

\footnotetext{
${ }^{1}$ Çalışmanın verileri 01.01.2020 tarihinden önce toplandığı için etik kurul kararı zorunluluğu taşımamaktadır.
} 
görüşerek ve doküman analizi ile veri toplanması ve çalışma grubuna farklı katılımcıların (yöneticilerin, sınıf rehber öğretmenlerin ve velilerin) alınması da inandırıcılığı artırmaktadır. Ses kaydı yapıldığı halde, katılımcıya her sorunun sonunda verdiği yanıt özetlenerek anında katılımcı teyidi sağlanmıştır.

b) Çalışmanın aktarılabilirliğini sağlamak için çalışmanın deseni, katılımı grubu, veri toplama araçları, veri toplama süreci ve veri analizi hakkında ayrıntılı bilgi verilmiştir.

c) Çalışmanın tutarlılığını sağlamak amacıyla belirtilmiş ham katılımcı görüşleri iki ayrı kişi tarafından kodlanmış ve elde edilmiş kodlamaların tutarlı olup olmadığının karşılaştırılması yapılmıştır.

d) Çalışmanın teyit edilebilirliğini sağlamak amacıyla veri toplama araçları, ham veriler, kodlamalar, notlar ve çözümlemeler ileride başkaları tarafından incelenebilecek şekilde saklanmaktadır.

\section{Bulgular}

$\mathrm{Bu}$ bölümde, okul-aile iş birliğine ilişkin temalara, kodlamalara ve doğrudan alıntılara yer verilerek yorumlar yapılmıştır. Veri analizi sürecinde elde edilen bulgular, katılımcıların unvanı ve okulun bulunduğu ilçenin sosyoekonomik konumuna göre de karşılaştırılmıştır. Bulgular incelendiğinde, bir yandan yönetici ve öğretmenler ile veli görüşleri arasında farklılıklar bulunduğu; diğer yandan bu farklılıkların katılımcıların ait oldukları okullara da yansıdığı anlaşılmaktadır. Çalışmada bulgular yorumlanırken yönetici, öğretmen ve veli görüşlerindeki benzerliklere ve okullar arasındaki farklılıklara dikkat çekilmiştir. Okul-aile iş birliğine ilişkin okul yöneticisi, sınıf rehber öğretmen ve velilerin görüşlerinin analizi sonucunda Şekil 1'deki temalar ortaya çıkmıştır:

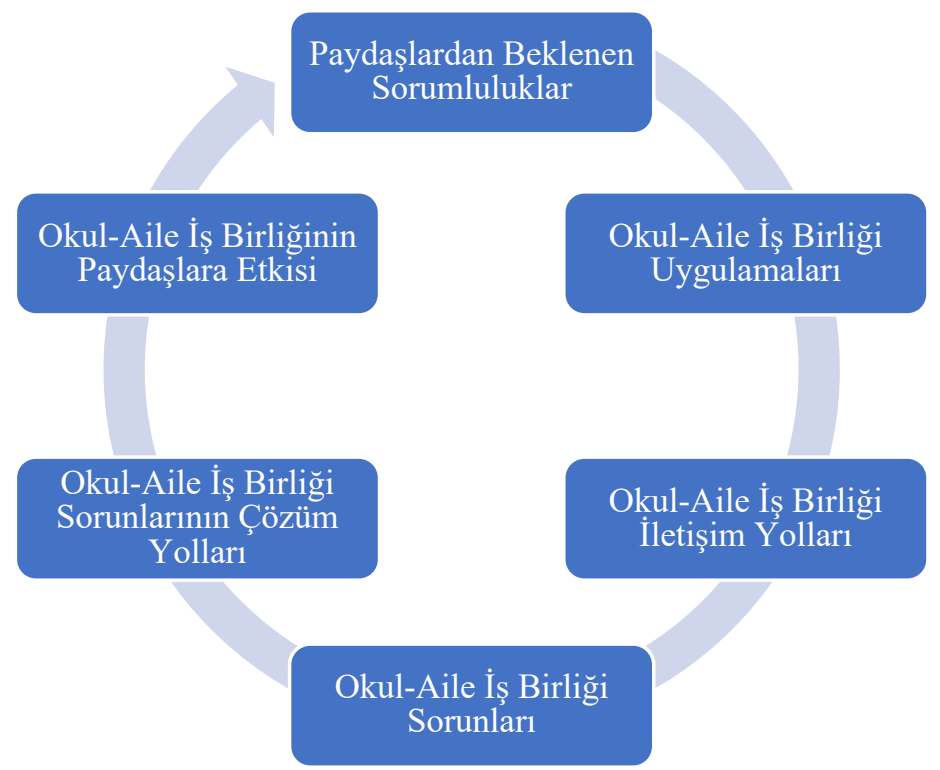

Şekil 1. Okul-Aile İş Birliği Temaları

\section{Okul-Aile İş Birliğinde Paydaşlardan Beklenen Sorumluluklar}

Katılımcılara okul-aile iş birliğinde paydaşlardan beklenen sorumluluklar nelerdir sorusu sorulmakla katılımcıların sorumlulukla ilgili farkındalık düzeyi ve birbirlerinden beklenen sorumlulukla ilgili görüşleri belirlenmeye çalışılmıştır. Okul-aile iş birliğinde paydaşlardan beklenen sorumluluklar teması okuldan beklenen sorumluluklar, veliden beklenen sorumluluklar ve okul-veli ortaklığ kategorileri altında sınıflandırılarak Şekil 2'de sunulmuştur.

Çalışma grubunda yer alan okul yöneticileri ve sınıf rehber öğretmenleri, okul-aile iş birliğinde kendi sorumluluklarını ifade etmişlerdir. Okul müdürleri ve sınıf rehber öğretmenleri, öğrencilere nitelikli eğitim-öğretim hizmeti vermek ve öğrenci başarısında iyi sonuç elde etmek için velilerle iş birliği yapmayı, aileleri tanımayı, veli beklentilerinden haberdar olmayı, velilerin okul etkinliklerine katılımını sağlamayı, öğrenci haklarını gözetmeyi ve velilerle sürekli iletişim içerisinde olarak gerekli konularda onları bilgilendirmeyi kendi sorumlulukları arasında görmektedirler. Yönetici ve öğretmenler iş birliği oluşturmada kendi sorumluluklarını şöyle tanımlamışlardır:

Okul, ögrencinin gelişsim düzeyini takip edebilmek için aile ile sürekli olarak iş birliğinde olmalıdır. ...Öğrenciyi geliştirmek için onu ve ailesini tanımak gerekir. Tanımak içinse aile ile iş birliği içinde olmamız lazım (YY).

Okul, velilerle iş birliği içinde olmalı ve onların okulda düzenlenen etkinliklere katılımını sağlamalıdır. Okul öğrencinin ilk terbiyesini aldı̆̆ aileyi iyi tanımal, ailenin okuldan beklentilerinin ne olduğunu bilmeli, okuldaki eğitim ve ögretim koşullarıyla ilgili veliyi bilgilendirmelidir. Okulun görevi her ögrencinin olumsuz davranışlarını törpüleyerek onu doğru yöne yönlendirmek ve vatansever bir birey olarak yetişstirmektir $(O Y)$. 
İster okul yönetimi ister öğretmenler kaprislerini bir kenara koyarak velilerle iş birliğine açılk olmalıdır... Öğrencisinin eğitim, ögretim ve diğer haklarını gözetmelidir (DY).

Öğretmen bu iş birliğinin oluşmast için veliyle hep iletişimde olmall, aile ile iç içe olmall, ailedeki durum ve sorunları bilmelidir çünkü eğer ailede bir sorun varsa, bu mutlaka ögrrenciye yansiyor (YÖ2).

\section{Okuldan Beklenen Sorumluluklar}

İyi eğitim-öğretim ortamı sağlama, velilerle iş birliğine açık olma, veliyi bilgilendirme, ailede verilen eğitimi okulda devam ettirme, aileyi iyi tanıma, ayrımcı yaklaşım sergilememe, öğrenciye birey olarak yaklaşma, olumsuz öğrenci davranışlarını törpüleme, öğrenciyle ilgilenme, nitelikli bireyler yetiştirme, veli beklentilerinden haberdar olma, veli ile iletişim kurma
Veliden Beklenen Sorumluluklar

Çocuğunun eğitim-öğretimiyle ilgilenme, okuldaki öğretimi evde devam ettirme, okulla iletişimde olma, Mektepli Kitapçası'nı takip etme, veli toplantisina ve okul faaliyetine katılma, çocuğu okula düzenli gönderme, çocuğun doğru beslenmesini ve iyi uyumasinı sağlama, çocukla sağlıklı iletişim kurma, evde öğrenme ortamı yaratma, okulun eğitim ve öğretim istemlerini karşılama, çocuğun ders araç gereçlerini temin etme

\section{Okul-Veli Ortaklı̆ğ}

Birlikte hareket, esit katk1,

karşılıklı samimiyet, birbirlerini destekleme ve anlama

Şekil 2. Okul-Aile İş Birliğinde Paydaşlardan Beklenen Sorumluluklar

Katılımcı velilere göre de kaliteli eğitim-öğretim hizmeti verilmesi, öğrencinin öğrenim durumuyla ilgili sürekli bilgilendirmenin yapılması ve öğrenciye bireysel yaklaşılması okulun üstlenmesi beklenen sorumluluklardır. DD kodlu okulun velilerinin beklentileri arasında, öğretmenlerin öğrenci başarısı ve veli statüsü bakımından öğrenciler arasında ayrımcılık yapmaması da bulunmaktadır. Bu beklentinin YD ve OD kodlu okullarda gözlenmemesi dikkat çeken bir bulgudur. Veliler, okuldan beklenen sorumluluklarla ilgili aşağıdaki görüşlerde bulunmuşlardır:

Öğretmenlerin çocuğumun öğrenimiyle ilgilenmesi gerektiğini düşünüyorum (YV2).

Öğretmenin çocuğumun öğrenimiyle ilgilenmesi, davranışlarını takip etmesi ve beni bilgilendirmesi gerektiğini düşünüyorum (OV4).

Çocuklarımın bilgili, eğitimli olmasını istediğim için onları okula göndermekteyim. Bana göre okul da iyi bir eğitim ve ögretim ortamı yaratılmalı, ögrenciler arasında ayrımcllk yapılmamalı ve çocuğuma birey olarak yaklaşılmalıdır (DVI).

Okulda öğretmen çocuğun evde yaptı̆̆ ev ödevi ve sinıfta neyi öğrenip öğrenmediğiyle ilgilenmelidir. Öğretmen çocuğum bir yanlış yaptığında bana haber vermelidir ki, ben zamanında gerekli tedbirleri alabileyim. Ë̆itim ve öğretim, öğrencinin velisine, başarısına ve ögrenim durumuna göre ayrımcllı yapllmadan verilmelidir (DV4).

Okul yöneticileri ve sınıf rehber öğretmenleri de okul-aile iş birliğinde velilerden beklenen sorumlulukları dile getirmişlerdir. Bunlar, çocuğu için evde ders çalışma ortam düzenleme, evde de eğitimin-öğretimin sürekliliğini sağlama, okulun eğitim-öğretime ilişkin istemlerini karşılama, okulla iletişimde olma, çocuğunun doğru beslenmesini temin etme, çocuğunun uyku düzenine dikkat etme ve çocuğunu etkileyebilecek sorunları öğretmenle paylaşma olarak belirlenmiştir. Velilerden beklenen sorumluluklarla ilgili yönetici ve öğretmen görüşleri aşağıda sunulmuştur:

Evde ögretim koşullarının sağlandı̆̆ bir alan oluşturmalıdır. Veli bizim okulda öğrettiklerimizi evde devam ettirmelidir. Veli bunlar yapmadı̆̆ında okulla aile arasında bir tutarsızlık oluşuyor. Her bir okulun ögrencinin eğitim ve ögretimiyle ilgili belli istemleri vardır ve aile de o istemleri karşılamalıdır. Veli çocuğunun aralıksı olarak okula gelmesini temin etmelidir (YY).

Her eğitim, ögretim yllının başında genel toplantılarda velilere söylüyorum: Sizin göreviniz çocuğunuzun eğitim ve ögretimiyle ilgilenmek, çocuğunuza lüks bir oda ayırmak değil sadece öğrenimini gerçekleştirebileceği bir alan oluşturmak, okuldaki veli toplantılarına katılmak, onun doğru beslenmesini temin etmek, ona zaman ayırmak, onunla sağglklı iletiş̧im kurarak onlarla ilgili beklentilerinizi ve onların görevlerini konuşmanızdır (DY).

Düşünüyorum ki, ögrencinin eğitim ve öğretimiyle biz ilgileniyorsak, veli de evde bunu devam ettirmelidir (YÖ1).

Veli ögretmenle iletişimde olmalıdır. Bir sorun varsa bunu mutlaka öğretmenle paylaşmalıdır. Tabii ki öğretmen de bu sorunu bildiğini öğrenciye hissettirmeden ona yardımcı olabilir. Veli çocuğunun iyi bir öğrenim görmesini istiyorsa, evde ona okuması için sakin bir yer ayarlamal, gereken ders araç gereçlerini almal, iyi uyumasını, doğru beslenmesini sağlamalıdır (YÖ2). 
Veliler okul-aile iş birliğinde kendi sorumluluklarını çocuklarının eğitim-öğretimiyle ilgilenme, çocuğu okula göndermeden önce kitap ve defterinin çantada olup olmadığını kontrol etme, Mektepli Kitapçası'nı ${ }^{2}$ sürekli takip etme ve okulla iş birliği yapma olarak görmektedirler. Bu bulgu, katılımcı velilerin sorumluluklarının farkında olduğunu göstermesi bakımından umut vericidir. Veliler, çocuklarına iyi bir gelecek oluşturmak için kendi sorumluluklarıyla ilgili şu görüşlerde bulunmuşlardır:

Ailenin de çocuğunun eğitim ve ögrenimiyle ilgilenmesi gerektiğini düşünüyorum. Ben çocuklarımın ev ödevleriyle ilgileniyorum. Çocukların Mektepli Kitapçası'nı takip ediyorum (YV2).

Veli her gün çocuk geldiğinde çocuktan okuldaki öğretim durumunu sormall, evde derslerini nasıl yaptığını takip etmeli, derse hazırllkl gidip gitmediğini öğrenmeli, çocuğunu okula gönderirken çantasına bakmalı, günün ders kitap ve defterlerinin çocuğunun çantasında olup olmadiğını kontrol etmeli, Mektepli Kitapçası'nı takip etmelidir (DV2).

Benim verdiğim eğitimi okul devam ettirmiyorsa ya da okulun verdiği öğretimi ben devam ettiremiyorsam o zaman çocuğun iyi bir geleceği olamaz. Onun için de biz bir iş birliği yapmak zorundayız. Biz de okulun tüm faaliyetine katılmakla veli görevimizi yerine getirmeye çalışlyoruz... (DV3).

Veli olarak evde çocuğumun derslerine yardımcı olmalı ve her gün derse hazırlıkl göndermeliyim. Çocuğumun derslerindeki zayıf yönlerini ortadan kaldırmak için elimden geldiği kadar yardım etmeye çallşıyorum. Çocuklarım okuldan geldiğinde Mektepli Kitapçası'na bakıyorum. Mektepli Kitap̧̧ası'na öğretmenin ne yazdı̆̆ını merak ediyorum. Öğretmenler bugün okulda işlenen konuyla ilgili çocuğumun neyi, nasıl bildiğini veya bilmediğini not ediyor (DV4).

Okul yöneticisi, sınıf rehber öğretmeni ve veli görüşlerinden, okul-aile iş birliğinde sorumluluğu paylaşarak ortaklaşa üstlenmenin önemli görüldüğü anlaşılmaktadır. Okul yöneticileri ve sınıf rehber öğretmenleri, okul-aile iş birliğinde okul-veli ortaklığından birlikte çalışma, eşit oranda katkı sağlama, birbirini destekleme ve samimi olmayı anlamaktadırlar. Katılımcıların bu konudaki görüşleri şöyledir:

Okul-aile iş birliği deyince çocuğun eğitim ve öğretimiyle ilgili ailenin ve okulun birlikte çalışması olarak anliyorum...

Ĕger okul ve aile bu iş birliğine eşit oranda katkı sağlarsa, o çocuk sadece ailenin değil aynı zamanda vatanın da geleceği olmuş olur. Onun için de her iki taraf da birbirine gereken desteği göstermelidir diye düşünüyorum. Her iki taraf birbirine samimi olmalıdır. Bu iş birliğinde taraflar arasinda bariyer olmamalıdır (OÖ2).

Veliler de birlikte hareket etme ve karşılıklı anlayış göstermeyi her iki tarafın taşıması gereken sorumluluk olarak görmektedirler. Veli görüşlerinden örnekler de aşağıda sunulmuştur:

Okul-aile iş birliğini aile ve okulun birlikte çocuğu ĕgitmesi olarak algllyorum (YVI).

Okul-aile iş birliği aile ve okulun karşıllklı anlayış çerçevesinde birlikte çalışmasıdır. Veli ve öğretmen üstüne düşen sorumluluğu karş̧llıkl şekilde taşırsa, o öğrencinin güzel bir geleceği olabilir. Okulla hem birbirimizi anlamalı hem de zamaninda iş birliği yapmamı gereklidir (DV4).

Veriler incelendiğinde, gerek yönetici ve öğretmenlerin gerekse velilerin okulun öğrenci için iyi bir eğitimöğretim ortamı sağlaması, veliyi bilgilendirmesi ve öğrenciyle ilgilenmesi; velinin çocuğunun eğitim-öğretimiyle ilgilenmesi, okuldaki öğretimi evde devam ettirmesi, okul etkinliklerine katılması ve birlikte hareket edilmesi konusunda ortak beklentiye sahip oldukları anlaşılmıştır. Beklenen sorumluluklarla ilgili bulgular okul bakımından karşılaştırıldığında ortaya çıkan farklılıklar da şöyle özetlenebilir: Velinin okulun eğitim-öğretim istemlerini karşılaması, çocuğunu okula düzenli göndermesi, çocuğun iyi uyumasını ve ders araç gereçlerini sağlaması YD kodlu okulda; okulun velilerin beklentilerinden haberdar olması ve olumsuz öğrenci davranışlarını törpülemesi OD kodlu okulda; okulun öğrencinin eğitim-öğretim ve diğer haklarını gözetmesi, öğrenciyle ilgilenmesi, öğrenciler arasında ayrımcılık yapılmaması, öğrenciye birey olarak yaklaşılması, velinin çocuğa zaman ayırması ve çocukla sağlıklı iletişim kurması DD kodlu okulda beklenen sorumluluklardır.

\section{Okul-Aile İş Birliği Uygulamaları}

Bakü okullarında iş birliğinin niteliğini ve kapsamını ortaya çıkarmak amacıyla yöneltilen hangi uygulamaların gerçekleştirildiği sorusuna katılımcıların verdiği yanıtlar kodlanarak Şekil 3'te sunulmuş̧tur.

Öğrencinin eğitim-öğrenim durumu hakkında bilgi alışverişinde bulunmak ve okulda öğrencilere yönelik eğitim-öğretim kararları almak için veli toplantılarının yapılması, çalışma bulguları arasında en önemli görülen okulaile iş birliği uygulamasıdır. Katılımcı görüşlerinden, okullarda sınıf veli toplantısı, genel veli toplantısı ve değerlendirme sınav sonucu duyurma toplantısı olmak üzere farklı isimlerde veli toplantılarının düzenlendiği

\footnotetext{
${ }^{2}$ Mektepli Kitapçası, Azerbaycan’da 1 - 11. sınıf öğrencilerinin kimliklerinin, öğrenim gördüğü okulun, okul müdürünün, sınıf rehber öğretmenin ve sınıfın isminin yer aldığı; okul müdürünün ıslak imzasının ve mührünün bulunduğu; bir eğitim-öğretim yılındaki tüm derslerin ve değerlendirme notlarının, öğretmen ve veli bildirimlerinin, her haftada sınıf rehber öğretmen ve velinin imzasının yer aldığı okul-veli iletişim aracıdır.
} 
anlaşılmıştır. Sınıf veli toplantılarında, genellikle sınıfın genel eğitim-öğretim durumu konuşulmakta ve tartışılmaktadır. Katılımcılar sınıf veli toplantısıyla ilgili aşağıdaki yorumlarda bulunmuşlardır:

Her sinıfin sinıf rehber ögretmeni, sinlf veli toplantısı düzenliyor ve o zaman beni de davet ediyorlar. Bu toplantılara katılırken velilerimizin neleri tartıştı̆̆ını, ne gibi sorunlarının olduğunu öğrenmişs oluyorum (DY).

Genellikle çocuğuyla ilgili sorunların sınıf veli toplantısında konuşulması velilerin hoşuna gitmediği için bu konuları bireysel görüssmelerde konuşuyorum. Sinıfla ilgili genel konuları ise sinıf toplantısında konuşuyoruz (DÖ2).

Bu son senede okulda değerlendirme sinavı sonucu toplantısı, çocukların eğitim ve öğretimi, giyim kuşamıyla ilgili sinıf veli toplantısina katılmışımdır (DV3).

OD kodlu okula ilişkin doküman analizi sonucunda, Kasım 2019'da sınıf veli toplantılarının düzenlendiği, toplantıda öğrencilerin devamsızlık yapmasını ve hoş olmayan davranışlarda bulunmasını önlemek ve velilerin bilinçli bir şekilde iş birliği kurmasını temin etmek için velilere okul yönetimi ve öğretmenler tarafindan öğrencilerin okul devamlılı̆̆ı, okulun disiplin kuralları, veli ve öğrencilerin hak ve sorumlulukları hakkında bilgi verildiği bulgusuna ulaşılmıştır.

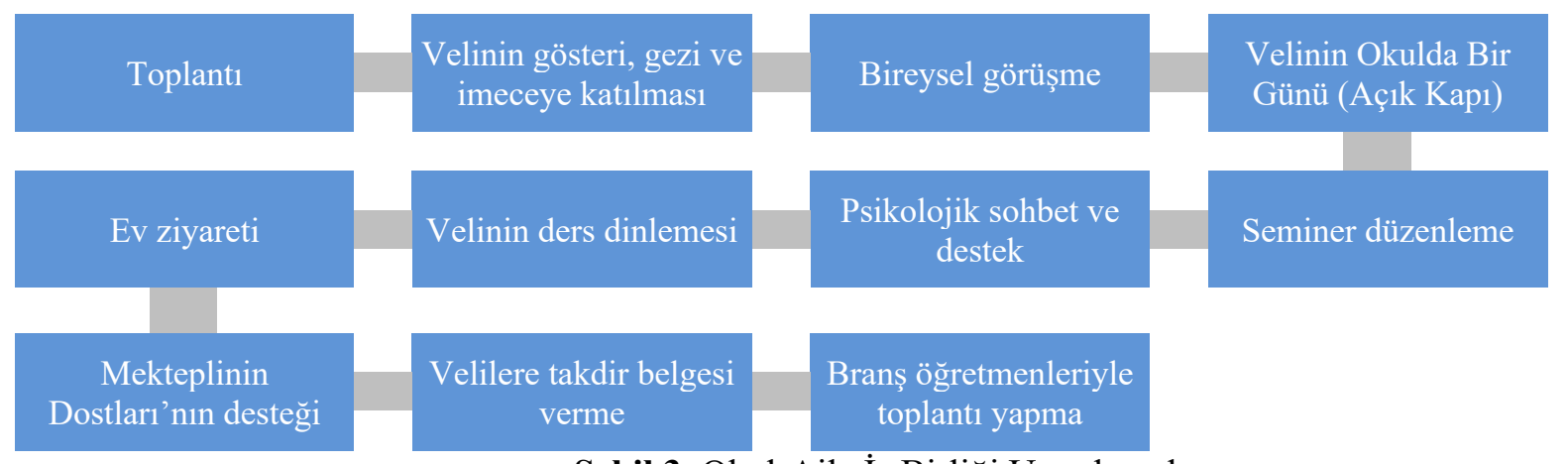

Şekil 3. Okul-Aile İş Birliği Uygulamaları

Okullarda yapılan düzey belirleyici değerlendirme sınavları öğrencilere bilgi düzeylerini test etme, konularla ilgili eksik yönlerini saptama ve bu eksiklerin giderilmesi yönünde planlama yaparak harekete geçme, zamanı iyi yönetme ve farklı soru tiplerini görerek kendini geliştirme şansı yaratmaktadır. Yapılan öğrenci değerlendirmesi sonucunun velilere duyurularak olası sorunların çözümünde veli katılımının sağlanması hem öğrenciyi başarıya ulaştırmak hem de okul-veli iş birliğini güçlendirmek için önemli görülen okul-aile iş birliği uygulamasıdır. DY'nin bu konuya ilişkin görüşü şöyledir:

Her düzey değerlendirme sinavindan sonra toplantı yaparak sonuçları sinıfların velileri ve ögretmenleri ile birlikte tartışıoruz. Bunu yapmakta amacımız velilerimize çocuklarının bilgi düzeyleri hakkında bilgi vermek ve akademik başarılarını daha da artırmak için neler yapılabileceğine karşılıklı karar vermektir (DY).

Doküman incelemesinde, YD kodlu okulda Kasım 2019, OD kodlu okulda Aralık 2019'da, 9. sinıfların velileri için düzey değerlendirme sınavının sonucunu ve mezuniyet sınavına hazırlık sürecini tartışmak amacıyla veli toplantısı yapıldığ 1 tespit edilmiştir. DD kodlu okulun web sitesi ve sosyal medya sayfasından da 2019'un eylül ve ekim aylarında 5,6 ve 9. sınıfların velilerine düzey değerlendirme sınavının sonuçlarını duyurmak ve velilerle birlikte önlemler almak için toplantı yapıldığı anlaşılmıştır. Bu bulgular, okulun öğrenci başarısını sağlamada veli desteğini önemli gördüğünü göstermektedir.

Okul, öğrenci ve velilerle ilgili genel konuların konuşulduğu, okuldaki gelişmelerle ilgili velilerin bilgilendirildiği ve kararların alındığı genel veli toplantısı da okul-aile iş birliği kapsamında gerçekleştirilen uygulamalardan biridir. Bu bulguya ilişkin elde edilmiş görüşler aşağıda sunulmuştur:

Genel veli toplantılart düzenleyerek okulda yapılacak projeler, uygulamalarla ilgili velilerimizi bilgilendiriyoruz. Bazen tüm velilere ulaşamadı̆̆ımızda en azından her sınıfin veli komitesinin başkanlartyla görüşüyoruz (OY).

Genel veli toplantıları yapıyoruz. Bu toplantılarda veliye çocuğun dersini okumuyor, okula gelmiyor, davranışı kötüdür gibi fikirler söylenmiyor. Genel toplantllarda genel sorunlarımı, beklentilerimiz nedir sorusuna hem veliler hem biz cevap arlyor, cevapları tartışlyor ve çözüme hep birlikte karar veriyoruz (DY).

OD kodlu okulla ilgili doküman analizinden de Ekim 2019 ve Şubat 2020'de genel veli toplantısı düzenlendiği; toplantıda öğrencilerin akademik başarısı, okula devamı ve yapılacak değerlendirmelerle ilgili görüşlerin paylaşıldığı; veli soru ve görüşlerinin dinlendiğine ilişkin bulgulara ulaşılmıştır. Bu bulgular katılımcı görüşlerini desteklemektedir.

Velilerin okulda düzenlenen gösterileri izlemeye gelmesi, gösterilerin düzenlenmesinde öğretmenlere destek olması ve öğretmenlerle birlikte gezilere katılması okulun sosyal faaliyetler düzenlediğini, velilerin de bu faaliyetlerde okulu desteklediğini ortaya koyan bulgulardır. Bu konudaki katılımcı görüşleri de şöyledir: 
Ilkokul sınıflarında düzenlediğimiz etkinliklere veliler daha aktif katıllyorlar. Veliler ister çocuğunun rol gereği olan elbiselerini temin etmek olsun ister etkinliği düzenlemek olsun, gösterileri izlemek olsun, bu konularda çok aktifler (DY).

Çocuklarımın rol aldı̆̆ yeni yıl, Nevruz şenliklerini ve tarihimizle ilgili düzenlenen etkinlikleri izlemeye geliyorum. Okulda resim sergisi düzenlenmişti ve kızımın resim yapma yeteneği olduğu için ben de sergiyi izlemeye gelmiştim (DV1).

Gezilere sınıfimızın branş ögretmenlerini ve velileri davet ediyoruz ki, ister ögretmen-ögrenci ister ögretmen-veli arasında samimi ortam yaransin (OÖ1).

Okul gezisi düzenlendiğinde çocuklarımla birlikte ben de katıllyorum. Gezi zamanı hem çocuklarla hem de ögretmenle iletişim kurma şansım oluyor (YV4).

Veli ile çocuğunun birlikte hoş vakit geçirmesi ve karşılıklı iletişimin sağlanması açısından, okullarda velilerin de katıldığı okuma günü etkinlikleri yapılması, okul-aile iş birliği kapsamında yürütülen önemli bir uygulamadır. Okullarda öğretmen, öğrenci ve velilerin katılımıyla gerçekleştirilen imeceler de paydaşların okula bağlılı̆̆ını artırabilecek bir uygulama olarak değerlendirilebilir. Bu konudaki görüşlere aşağıda belirtilmiştir:

Okuma günü yapıyoruz ve velilerimiz çocuklarıyla gelip okuma gününe katılıorlar (OÖ1).

Okulda yapılan imeceye katılıorum (DVI).

Katılımcı görüşlerinden okul-aile iş birliği kapsamında, her eğitim-öğretim yılında iki kez "Velinin Okulda Bir Günü (Açık Kapı)" adlı uygulamanın gerçekleştirildiği anlaşılmıştır. Bu uygulamanın gerçekleştirilmesi, velinin okulun fiziksel koşulları ve öğrenim ortamıyla tanışmasını ve öğretmenlerle görüşebilmesini sağlamaktadır. Uygulamaya ilişkin katılımcı görüşleri aşağıda sunulmuştur:

Senede iki kez "Velinin Okulda Bir Günü” isimli uygulama yapıyoruz. Lobide öğrencilerimizin el işlerini sergiledik. Veliler çocuklarının akademik başarılarıyla ilgili bilgi sahibi oldular. Veliler istedikleri sınıfa girip dersleri dinlediler (YY).

YD kodlu okulun web sitesi ve sosyal medya sayfasından da öğretim yılında iki kez "Velinin Okulda Bir Günü" adlı uygulamanın yapıldığı anlaşılmıştır. Paylaşılan haber ve fotoğraflardan, bu uygulama kapsamında velilerin okul binasını gezerek okulun fiziki koşulları ile tanıştıkları tespit edilmiştir. Uygulama kapsamında, veliler için okulun giriş katında öğrencilerin okulun yaratıcılık atölyesinde yaptıkları el işleri sergilenmiş, velilerin ders dinlemelerine firsat verilmiş ve okul-veli iş birliğine ilişkin seminer düzenlenmiştir. Doküman analizinde saptanan bulgu okul yöneticinin görüşünü destekleyici niteliktedir. OD kodlu okulda "Velinin Okulda Bir Günü" uygulaması gerçekleştirilirken veli görüşlerini öğrenmek amacıyla veli memnuniyet anketinin yapıldığ 1 bulgusuna da ulaşılmıştır.

Okullarda veli ile iş birliğini sağlıklı şekilde yürütmek, velinin çocuğuyla, öğretmenin öğrenciyle ve veliyle doğru iletişim kurmasını sağlamak için öğretmen ve velilere bilinçlendirici seminerler verilmesi de okul-aile iş birliği kapsamında gerçekleştirilen bir uygulama olarak saptanmıştır. Bu uygulamaya ilişkin katılımcı görüşleri aşağıda sunulmuştur:

Başarılı okul-aile iş birliği oluşturmak için düzenli şekilde öğretmenler, veliler ve ögrenciler için seminerler düzenliyoruz. Öğretmenler için ilk semineri kendim düzenledim. Seminerde iyi ögretmen nasıl olmalıdır, veliye ögrenciye yaklaşım nasıl olmall, sorunlar ve sorunların nedenleri nasıl belirlenmeli ve çözüm zamanı hangi yöntemler kullanılabilir gibi konular konuşuldu. İkinci semineri ise bir psikolojik hizmet ve çocuk gelişim merkezinin desteğiyle düzenledik. Veliler için yetişkin dönemi sorunları, intihar ve intiharı önleme, cinsel şiddet, derslerden geri kalan ögrenci vb. konularda seminerler düzenledik. Öğrenciler için ise zararlı alışkanlıklarla ilgili seminerimiz oldu (DY).

Çocuklarımızın psikolojik gelişimi ve onlarla iletişim kurmamızla ilgili seminerler yapıldı ve biz de gelip katıldık (DV3).

YD kodlu okulun web sitesinden, 29 Ekim 2019 tarihinde okulda ilçe istihdam merkezinin danışmanı ve “....." isimli iş merkezinin eğitmeni tarafından öğrenci ve velilere öğrencilerin meslek seçimiyle ilgili bilgilendirici seminer yapıldığı bulgusuna ulaşılmıştır. Doküman analizinden, DD kodlu okulda yöneticinin velilere akran zorbalı̆̆ı hakkında seminer verdiği ve bu konunun velilerle tartışıldığ 1 bulgusu elde edilmiştir. Kasım 2019'da velileri bilgilendirmek için akran zorbalığıyla ilgili seminerin OD kodlu okulda da verildiği saptanan bir bulgudur.

Velilerin derslere katılıp, dersi dinlemesi öğrenci başarısını olumlu etkilemektedir. Katılımcı görüşlerinden velilerin derse katılabilmeleri için okullarda gerekli koşulların oluşturulduğu anlaşılmıştır. Velilerin derse katılmaları, öğretmenlerin kaliteli öğretim ortamı oluşturmada daha dikkatli olmalarını, velilerin çocuklarının öğrenim durumunu kendi gözleriyle görmesini ve öğrencinin derse daha hazırlıklı gelmesini ve derste aktif olmasını sağlamada etkili bir uygulamadir. Velilerin bu konudaki görüşleri de şöyledir:

Beni her zaman çocuklarımın başarılarından dolayı okula çağırıyor ve gayet güler yüzle karşılıyorlar. Sıkça okula gelip ögretmenlerle görüşürüm. Bazen çocuğumun haberi olmadan okula gelip derslerine katılarak ögrenim durumunu kontrol ediyorum... (DV3).

Okula geldiğimde derslere girip çocuğumun dersini dinlerim (DV1).

DD kodlu okulun web sitesinden, öğretmenlerin açık derslerine okul yönetimiyle birlikte velilerin de katıldığ tespit edilmiştir. Bu bulgu, okul yönetiminin öğrenim koşullarıyla ilgili velilerin de bilgi sahibi olmasına önem verdiğini ortaya koymaktadir. 
Katılımcı görüşlerine göre, farklı durumlarda öğretmen ve veliler tarafından ev ziyaretlerinin yapılması öğretmen-veli, veli-veli arasındaki iletişimi, iş birliğini güçlendirmektedir. Katılımcıların ev ziyaretiyle ilgili görüşleri de şöyledir:

Öğrencim hastalandığında bir süre okula gelmediğinde evine gidiyorum. Sinıfimda bir öğrencim hasta oldu, evine gittik. Tüm veliler, sınıf veli komitesi başkanı, hep birlikte o ögrencimize hem maddi hem manevi yardım sağladı. Öğrencimizi yalnız birakmadık (YÖ1).

Sinıfta herhangi birimizin bir sorunu olduğunda birbirimize yardım etmeye çalışlyoruz. Bir öğrencimiz hastalandiğında ögrretmenle hepimiz toplanıp o çocuğumuzun evine gittik, elimizden geldiği kadarıyla maddi yardımda bulunduk (YVI).

Okullarda gerçekleștirilen Mekteplinin Dostu uygulamasının temel amacı, öğretmen ve öğrenciler için daha güvenli bir ortam yaratmak; psikolojik destek sağlamak; düzenli olarak öğrenci, veli ve öğretmenlerle ilgili bilinçlendirici çalışmalar yürütmektir. Bir yönetici ve velinin bu konudaki görüşü aşağıda sunulmuştur:

Okulumuzda neredeyse üç senedir "Mekteplinin Dostu" uygulaması gerçekleştirilmektedir. "Mekteplinin Dostu" uygulamasında amaç okul-ögrenci-veli iletişimini sağlamak ve öğrenciye kendini gerçekleştirme firsatı yaratmaktır. Bu uygulamanın gerçekleştirilmesinde gençler rol almaktadır. Onlar mütemadiyen öğrencilerle iletişim kuruyorlar. Sorunları olan veya yardıma ihtiyacı olan öğrenciler öğretmenlerine, psikoloğa, ailesine söyleyemediklerini Mekteplinin Dostları'na söylüyorlar $(O Y)$. (OVI).

Toplantılarda Mekteplinin Dostları’yla görüşüyoruz. Onlar bize çocuklarımıza nasıl yaklaşmamızla ilgili bilgi veriyorlar

DD kodlu okulda, çocuğunun eğitim-öğrenimini destekleyen velilere takdir belgesinin verilmesi velilerin okulla iş birliği yapmasını teşvik etme ve değerlendirme açısından önemli bir bulgudur. Bir yöneticinin bu konudaki görüşü şöyledir:

Velilerimiz için yeni uygulama başlattık. Her ay her sınıfin rehber öğretmeninden sınıfinın başarılı öğrencilerinin listesini alıyorum. Aralık ayında her sinıfin başarılı ögrrencilerinin velilerine takdir belgesi vereceğiz. Bunu yapmakta amacımız, velileri çocuğunun eğitim ve ögrenimiyle daha fazla ilgilemesine motive etmektir. Bir ön deneme yaptı, iyi sonuç verdiğini gördük (DY).

DD kodlu okulun web sitesinden, Aralık 2019'da “Velinin Okulda Bir Günü” etkinliği düzenlendiği, bu etkinlikte de çocuğunun eğitim ve öğrenimiyle ilgilenen velilere takdirname verildiğinin gözlemlenmesi, katılımc1 görüşünü destekleyen bir bulgu olarak değerlendirilebilir.

Bulgulardan, okul-aile iş birliğini sağlamak için velilerin etkinliklere katılımı, yüz yüze bireysel görüşme, toplantı, Velinin Okulda Bir Günü (Açık Kapı), seminer, Mekteplinin Dostu ve ev ziyareti gibi uygulamaların yapıldığı konusunda yönetici, öğretmen ve velilerin ortak görüşte oldukları anlaşılmıştır. Mekteplinin Dostu uygulaması ve sinıf rehber öğretmeninin branş öğretmenleriyle toplantı yapması yalnızca OD kodlu okulda; velilere takdir belgesi verme, velilerle birlikte ders dinleme ve imeceye katılma ise DD kodlu okulda gözlenmiş bulgulardır.

\section{Okul-Aile İş Birliği Sürecinde İletişim Yolları}

Okul-aile iş birliğinin güçlendirilmesinde etkili iletişimin kurulması önemli görüldüğü için katılımcılara okul-aile iş birliği sürecinde iletişimin nasıl sağlandığı sorulmuş ve elde edilmiş cevapların kodlamaları Şekil 4'te sunulmuştur.

\section{İletişim Aracı ve Kaynağı}

Mektepli Kitapçası, telefon, WhatsApp grubu, şikâyet ve öneri kutusu, ilan levhası ve davetiye
Öğrenci ve veli komite başkanı

Şekil 4. Okul-Aile İş Birliği Sürecinde İletişim Yolları

Okul yöneticisi ve sınıf rehber öğretmenlerin velilerle iletișimi sağlarken kullandıkları en önemli iletișim aracı telefon iken; velilerin tercihi, öğrencinin öğrenim durumundan ve öğretmenin iletmek istediği bilgiden haberdar olmak, öğretmenleri sıkça rahatsız etmemek ve daha detaylı bilgi elde etmek için Mektepli Kitapçası olmuştur. Katılımcı görüşlerinden örnekler aşağıda sunulmuştur:

Mektepli Kitapçası ögrrencinin öğrenimindeki gelişmeyi takip etmek için önemlidir. Velinin her zaman okula gelme şansı yoktur ama o Mektepli Kitapçası aracılığıyla çocuğunun okulda nasıl davranış sergilediğini öğretmen yorumlarından öğrenmiş oluyor (OÖ2).

Mektepli Kitapçası'na bakarak çocuğumun ögrenim durumunu takip edebiliyorum. Öğretmen Mektepli Kitapçası'na hem günlük biçimlendirici değerlendirme sonucunu hem de sonuç özetleyici değerlendirme sonucunu yazıyor. Aynı zamanda öğretmenin 
bir şikâyeti olduğu zaman da yazabiliyor. Ben çalışan bir anne olduğum için akşam eve geldiğimde öğretmenin yazdıklarından bugün çocuğumun okulda ne yapmış olduğunu öğrenmiş oluyorum (YV3).

Çocuklarım her okuldan geldiğinde Mektepli Kitapçası'nı kontrol ediyorum. Her ders haftasının sonunda öğretmenlerin notlarını okuyor, imzamı atıyorum ki, ögretmen evde çocukla ilgilendiğimi bilsin (DV3).

Okul-aile arasındaki bilgi akışı duruma göre değişmekte; iletişim bazen telefon, sosyal medya, ilan levhası, şikâyet ve öneri kutusu aracılığ 1 bazen de öğrenci aracılığılyla sağlanmaktadır. Aşağıda katılımcı görüşlerinden örnekler sunulmuştur:

Okulun giriş katında veli ve ögrencilerimizin görüşlerini öğrenmek için şikâyet ve öneri kutumuz vardır. Genelde okulda yapılacak açık kapı, genel toplantılar ve etkinliklerle ilgili bilgileri velilere okul binasının girişinde bulunan ilan levhasıyla duyuruyoruz $(O Y)$.

Veli toplantısı ve okul etkinlikleriyle ilgili bilgileri velilere ögrenciler, WhatsApp ve telefon aracılı̆̆lyla iletiyoruz (DY).

Genel ve sınıf toplantılarının olacă̆ını ilk çocuktan öğreniyorum. Sonra sınıf rehber ögretmeni telefonla arayarak söyler (DV3).

Katılımcı görüşlerinden, sınıf veli komite başkanının öğretmen mesajları ve sınıf veli toplantısı zamanının velilere iletilmesine ve sınıf ihtiyaçlarını karşılamak için velilerden para toplanmasına aracılık ettiği, gezilerde öğretmenlere yardımcı olduğu ve belirli konularda velileri temsilen görüşünün alındığ1 anlaşılmaktadır. Bu konudaki katılımcı görüşleri şöyledir:

Okulda genel veli toplantısı yapacağım zaman sınıf rehber öğretmenlerine davetiye veriyorum. Onlar da sınıf veli komitesi başkanlarına veriyorlar. Sınıf veli komitesi başkanı da velilere söylüyor (YY).

Öğretmenler kurulu toplantısına okul-veli komitesinin başkanını davet ediyoruz. Onun da görüşlerini alıyoruz. Bazı toplantılarda tüm velilere ulaşamadığımızda en azından her sınıfin veli komitesinin başkanıyla görüşüyoruz (OY).

Gezilerde ögretmene yardımcı olmak için veli komitesi olduğum için kendim de katıllyorum (YV1).

Veli komitesi başkanıyım. Bir sene önce sınıf ihtiyaçlarımızı karşılamak için para topluyorduk. İş defterleri, tahta kalemi vb. kırtasiye ürünleri alıyoruz. Bunları almamı için para toplayanda velileri bulamıyordum veya para isteyince kızıyorlardı (YV4)

Sınıf veli komitesi başkanı olduğum için sınıf rehber ögretmenimiz toplantı zamanını beni arayıp söylüyor, ben de velilere iletiyorum (OV1).

Okul-aile iş birliğinde iletişimi sağlamada telefonla görüşme, öğrenciyle bilgilendirme, Mektepli Kitapçası, veli komite başkanıyla bilgilendirme, WhatsApp grupları ve ilan levhasından yararlanma yönetici, sınıf rehber öğretmeni ve veli görüşlerinde saptanan ortak bulgulardır. Üç okul arasında belirlenebilen tek fark, YD kodlu okulda davetiye mektubunun; OD kodlu okulda ise şikâyet ve öneri kutusu ile ilan levhasının iletişim aracı olarak kullanılması olmuştur.

\section{Okul-Aile İș Birliği Sorunları}

Okul-aile iş birliğinde yaşanan sorunları saptamak amacıyla katılımcılara iş birliği sürecinde karşılaştıkları sorunlar sorulmuş ve elde edilmiş cevaplar kodlanmıştır. Elde edilmiş kodlamaların belirli kategorilere ayrıldığ fark edilmiştir. Kodların sınıflandırılması sonucunda, okul-aile iş birliği sürecinde yaşanan sorunların okuldan, veliden ve öğrenciden kaynaklandığı anlaşılmıştır. Şekil 5 'te okuldan kaynaklı sorunlarla ilgili kodlamalara yer verilmiştir.

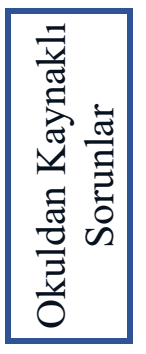

Öğretmen kaynaklı: öğrenciler arasında ayrımcılık yapma, mesleki yetersizlik, öğrenciye bireysel yaklaşmama, Mektepli Kitapçası'na değerlendirme notunu yazmama, ders yapmama, çalışma kitabı almaya zorlama, öğrenciyi vurma, öğrenciyi motive etmeme, görevini yerine getirmeme, açık kapı gününe katılmama, öğrencileri toplumun geleceği gibi görmeme; yönetim kaynaklı: iş birliğine açık olmama, öğretmenin tarafını tutma, ders araç gereçleri için para toplama, okul formasını her yıl değiştirme; deneyimli psikoloğun olmaması ve psikoloğun öğrenciyle ilgilenmemesi; okulda fiziki koşulların iyi olmaması

Şekil 5. Okul-Aile İş Birliğinde Okuldan Kaynaklı Sorunlar

Bulgulara göre, okul aile iş birliğinde okuldan kaynaklı sorunlar, öğretmenlerin mesleki yetersizliğinin ve görev bilincine sahip olmamasının, okul yöneticisinin iş birliğine açık olmamasının, okul psikoloğunun mesleki açıdan deneyimli olmamasının ve okuldaki fiziksel koşulların iş birliğini gerçekleştirmeye uygun olmamasıdır. Okuldan kaynaklı sorunlar arasında en yüksek frekans, öğretmenlerin öğrenci başarısına ve veli statüsüne göre öğrenciler arasında ayrımcılık yapması olmuştur. Öğretmenin görev bilincine sahip olmadığını gösteren bu bulguya DD kodlu okulda ulaşılması, o okulun velilerinin öğretmenin ayrımcılık yapmaması konusunda neden beklentiye girdiğini açı̆̆a kavuşturmaktadır. Bu konuda belirtilen görüşler şöyledir: 
İki çocuk kavga ettiğinde velisi bana geliyor. Veli ilk önce sinlf rehber öğretmene yaklaşmall, sorunu onunla çözmelidir. Veli ögretmenle değil benimle görüşüyor çünkü öğretmenin konuya yaklaşıım doğru olmuyor. Hangi ögrenci derslerinde başarıllysa ya da hangi ögrencinin ailesi çocuğuna ilgi gösteriyorsa öğretmen o ögrencinin tarafinı tutuyor. Kavgada o ögrrenciye hak veriyor (DY).

Bazı ögretmenlerimizin ögrenciler arasında ayrımcılık yapması, belli ögrrencilerle çalıșması, diğer ögrrencileri ders sürecine katmamast velilerimizin en önemli şikâyetleri arasinda yer alır (DÖ1).

Bir keresinde okula öğretmen çocuklar arasında ayrımcllı yaptı̆̆ için gelmişstim. Hoca dersinde hep başarılı olan çocuklarla ilgileniyordu. Benim çocuğumdan ders falan sormuyordu (DVI).

Sorunlardan biri de öğretmenlerin ögrenciler arasında ayrımcllı yapmasıdır. Öğretmenler öğrencilere kendi bilgi ve yeteneklerine göre değil, velilerine göre yaklaşım sergiliyorlar (DV4).

Aşağıdaki görüşlerde saptanmış öğretmenlerin öğrencilerle sağlıklı iletişim kuramaması ve sınıfı yönetememesi gibi bulgular, öğretmenin mesleki yetersizliğinden kaynaklanan sorunlar olarak değerlendirilmiştir:

Öğretmenin çocuk psikolojisinden haberi yoktur, üniversitede bu eğitimi tam almamış ve kendini bu konuda geliştirmemiştir. İnsan tipi, insan karakteri nedir, hangi tip insana nasıl davranılır, bunları bilmiyor (DY).

Bazen derslerde öğretmenin sinıf yönetiminde küçük kusurları oluyor. Dersinde öğrenciler gürültü yapıyorlar... (DV2).

Öğretmenin öğrenciyle ilgilenmemesi ve öğrenciye bireysel yaklaşmaması gibi öğretmen kaynaklı sorunlar, öğretmenin görev bilincine sahip olmadığını ortaya koyan bulgulardır. Örneğin:

Öğretmen okulun itibarında kendisinin bir rolü, görevi olduğunu unutmus gibi davranıyor. Sinıf rehber öğretmeni görevini yerine getirmiyor. Sinlf rehber öğretmeni öğrenci derse gelmiyor deyip duruyor. Okula gelmeyen öğrenciyle benden çekindiği için ilgileniyor. Öğretmen her ögrrencisine bireysel yaklaşmalıdır ama öğretmen öyle yapmıyor (DY).

Okulda ögretmenlerin bazıları maaş alıp eve gitmenin peşindeler. Çocuğa nasıl bireysel yaklaşırım, onu nasıl motive ederim, onun hangi becerileri var, o becerilerini nasll geliştirebilirim düşüncesinde değiller. Çocuklara bizim geleceğimiz gibi bakmiyorlar (DV4).

Okul-veli iş birliğinde en önemli iletişim aracı olan Mektepli Kitapçası'nda öğretmenin öğrencinin öğrenim durumuyla ilgili değerlendirme notu yazmaması velide çocuğunun öğrenim durumuyla ilgili bilgi oluşturmadığı için bu durum sorun olarak görülmüştür. Katılımcı görüşleri aşağıda sunulmuştur:

Velilerimin memnun olmadiğı şey, Mektepli Kitapçası'na çocuğunun öğrenim durumuyla ilgili sonuç özetleyici değerlendirme notunun veya biçimlendirici değerlendirmeyle ilgili bilginin yazllmamasıdır. Maalesef veliler bu konuda haklılar (DÖ1).

Öğretmen çocuğun Mektepli Kitapçası'na not yazmıyordu. Kitapça'da o ögretmenin dersiyle ilgili herhangi bir not görmüyordum (DVI).

Öğretmenin velilere iş defteri [çalışma kitabı] aldırtması ama iş defterinin kullanılmaması ve öğrenci çantasını ağırlaştırması aşağıdaki veli tarafından sorun olarak belirtilmiştir:

Aslında çocuklar sadece okul kitaplarlyla yetinseler iyi olur. Bizim zamanımızda iş defterleri yoktu ama kitaplardan gerekenleri okuyup yazıyorduk. Çocuklar okul çantasını taşıyamayacak duruma geldiler. İ̧̧ defterinin olmasını ilave masraf olarak görüyorum. Geçen sene aldıklarımızdan bazıların hiç kullanmadik, öylece evde duruyor. Gereksiz yere para harcamış olduk... (YV3).

Okul müdürünün, okulunda deneyimli okul psikoloğunun olmamasından, velinin ise okul psikoloğunun ilgisizliğinden yakınmaları, iki okulun psikolojik hizmet verme açısından yetersiz olduğunu ortaya koyan bulgulardır. Bu konuyla ilgili görüşler de şöyledir:

Okul-aile iş birliği konusunda fazla gayret göstersem de bu konuda bana yardımcı olacak deneyimli psikoloğum olmadĭg için bazen zorluklarla karş̧laş̧ıorum. Sorunu veliye doğru bir şekilde aktarmamız ve ona gerektiğinde psikolojik destek sağlamak için ögrrenciyi psikolojik açıdan iyi gözlemleme yeterliğine sahip, öğrenciye nasıl yaklaşmamızla ilgili bize yardımcı olacak, işinde deneyimli psikoloğa ihtiyacımız var (DY).

Çocuklarımın psikolojik durumu iyi değil. Diğer çocuğum kâh ağllyor, kâh gülüyor. İ̧̧ine kapanık bir çocuktur. Okul psikoloğu çocuklarımla ilgilenmemiştir (YV2).

DD kodlu okulun velileri, okuldan kaynaklı sorunlarla ilgili görüşlerinde eski yönetici ile şimdiki yöneticinin yönetim tarzını karşılaştırmış ve eski yöneticinin velilerle iş birliğine açık olmamasından kaynaklı sorunlara dikkat çekmişlerdir. Örneğin:

Önceki müdürümüz bizimle pek ilgilenmez, konuşmazdl, bir araştırma yapmadan hemen öğretmeni hakl bulurdu. Müdür, ögretmen o şeyi yapttğı halde o, ögretmenimiz öyle bir şey yapmaz diyordu (DVI).

Önceleri yapllan değerlendirme sinavlarında slk slk fotokopi parası toplanlyordu ama bu sene müdürümüz fotokopi parasinin toplanmasinı ortadan kaldırdı (DV4).

Öğretmenin ayrımcılık yapması, Mektepli Kitapçası'na değerlendirme notunu yazmaması, öğretmenin öğrenciye bireysel yaklaşmaması ve ders yapmaması yönetici, sınıf rehber öğretmeni ve veli görüşlerinde saptanan ortak sorunlardır. Psikoloğun öğrenciyle ilgilenmemesi, öğretmenin çalışma kitabı dayatması ve okul formasının her yıl 
değiştirilmesi YD kodlu okulda; açık kapı gününe bazı öğretmenlerin katılmaması OD kodlu okulda; öğretmenin ayrımcılık yapması, Mektepli Kitapçası'na değerlendirme notunu yazmaması, öğrenciye vurması, öğretmenin yalnızca maaş peşinde olması, psikoloji bilgisinin yetersizliği, sınıf rehber öğretmeninin görevini yerine getirmemesi, öğretmenin öğrenciye bireysel yaklaşmaması, öğretmenin öğrenciyi motive etmemesi, çocukları toplumun geleceği gibi görmeme, okulda deneyimli psikoloğun olmaması, yönetimin iş birliğine açık olmaması ve öğretmenin tarafını tutması DD kodlu okulda yaşanan okul kaynaklı sorunlardır.

Okul-aile iş birliğinde velilerden kaynaklı sorunlarla ilgili saptanmış bulgular Şekil 6'da sunulmuştur.

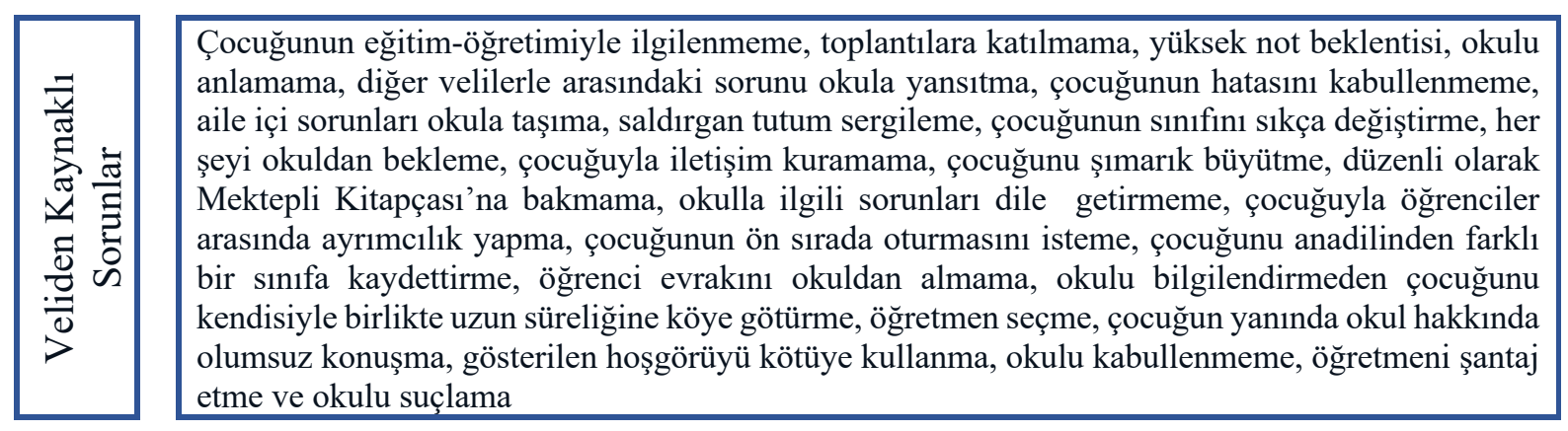

Şekil 6. Okul-Aile İş Birliğinde Veliden Kaynaklı Sorunlar

Yöneticilerin ve sınıf rehber öğretmenlerinin görüşlerinde, velilerin okulla iş birliği yapmaması, çocuğunun eğitim-öğrenimiyle ilgilenmemesi ve öğrenci sorunlarını çözmede okulu yalnız başına bırakması okul-aile iş birliğini ve öğrenci başarısını olumsuz etkileyen sorunlar olarak saptanmıştır. Örneğin:

Okulla iş birliği yapmayan, çocuğuyla az ilgilenen veli bizi endişelendiriyor çünkü o aileyi tanımadı̆̆ımız için onun çocuğu ile ilgili sorun yaşadığımızda karar vermemiz zorlaşlyor (OY).

Aileler her şeyi okuldan bekliyorlar, çocuklarıyla ilgilenmiyorlar. Ĕ̈itimi de, öğretimi de bizden bekliyorlar. Çocuğu okula gönderiyorum, siz yapın, diyorlar. Öğretmen işinin gereği biraz alttan aldıkça, düşünüyorlar ki okul bunu hakikaten yapmalıdır. Bu tür düşünce tarzı bizim yükümüzü artırmaktadır (DY).

Tek velili ögrencilerin eğitim ve öğretim sorunları daha fazla oluyor. Yarım ailelerin çocukları ilgilenenin olmaması yüzünden çevrenin olumsuz etkilerine karşı savunmasız kalıyor (DÖ2).

İletişim sürecinde okulun veliyi, velinin de okulu anlaması sağlıklı okul-aile iş birliği oluştururken; velinin okulu anlamak istememesi tam tersi bir sonuç doğurmaktadır. Velinin okulu anlamamasında, eğitim düzeyi düşüklüğünün etkisi olduğu anlaşılmaktadır. Katılımcı görüşlerinden örnekler şöyledir:

Öğrencileri kendimiz yetişstirdiğimiz için ne söylüyorsak hemen anlyyorlar ama veliyle böyle kolay anlaşılabilen bir ilişki kurmak zor oluyor... (YY).

Bazı velilerimizin eğitim düzeyinin yetersiz oluşu, modern çağa uygun dünya görüşü eksikliği. Ne kadar açıklama yapılsa da kendi fikirlerinde ısrarcıdırlar ve seni anlamıyorlar. Böyle velilerle iş birliği yapmak zor oluyor (OY).

Bazen veli senin dediğinin tam tersini anliyor. Onlarla sağlam iletişim kuramıyoruz. Öğrenciyle konuşup anlaşmak veliyle anlaşmaktan kolaydır (OÖ2).

Anne babaların kendi aralarındaki sorunu okula taşımaları hem okul yönetiminin işini hem de öğrenci öğrenimini olumsuz etkileyen bir sorundur. Katılımcı görüşleri:

Genç ailelerde anne ve baba kavga ettiğinde ve ayrıldı̆̆ında çocuğu kendi aralarında paylaşamaması okula da yansıyor. Anne söylüyor ki, çocuğu babaya göstermeyin, baba da çocuğunu görmek istiyor. Aile içi sorunlarını okula taşıyorlar. Bir diğer sorun, bir anne eşinden ayrıldığı için çocukları da kendisiyle köye götürüyor ve okulu da bilgilendirmiyor... Bu süre zarfinda çocuklar okula gelmedikleri için sinıfta kaliyor ve veli çocuğunun bu durumuyla ilgilenmiyor (YY).

Azerbaycan'da bazı okullarda eğitim-öğretim hizmeti Azerbaycan ve Rus dillerinde verilmektedir. Bazı velilerin Rus dilinde alt yapısı olmayan çocuklarının Rus dilinde öğretim görmesini istemesi öğrencinin öğreniminde başarısız olmasına neden olmaktadır. YY'nin görüşü:

Kendisi Rus Dili'ni bilmezken, çocuğunu Rus bölümünde okutmaya çalışan ısrarcı velilerimiz oluyor... (YY).

OD kodlu okulun yöneticisi, sınıf rehber öğretmeni ve velisi çocuğunun sınıfını sıkça değiştiren veliden ve onun öğrenciler arasında ayrımcılık yapmasından sorun olarak söz etmişlerdir. Çalışmada, bu sorunun gerek velinin kendi çocuğunun gerekse diğer öğrencilerin ruh sağlığını olumsuz yönde etkilediği bulgusuna ulaşılmıştır. Katılımcı görüşleri:

Bazı veliler sık sık çocuklarının sınıflarını değiştiriyorlar. Bunun için de çok gereksiz nedenler ileri sürüyorlar. Öğrenci bu sınıfa adapte oluncaya kadar veli onu diğer sinıfa değişstiriyor... (OY).

Bazı veliler mükemmel sinıf ve ögretmen arayışı içinde oldukları için onları memnun etmek zordur. Bizim sinıfta da böyle bir velimiz var. O önceki sınıfta yaptığını bizim sinıfta da yapmak istedi. Kendi yaptıklarıyla çocuğunu strese sokuyordu. Hatta 
öğrencilerimiz arasında ayrımcılık yapıyordu. Kendi çocuğunun akademik başarısını sınıfımızın en iyi başarısı olan çocuğundan üstün görüyordu (OVI).

Velinin çocuğunun notunun yüksek yazılmasını ve çocuğunun ön sırada oturmasını istemesi de saptanan veli kaynaklı sorundur. Velinin öğretmenden yüksek not yazmasını istemesi velinin çocuğunun gerçek öğrenme durumundan çok notuyla ilgilendiğini ortaya koyan bulgudur. Velinin çocuğunu ön sırada oturmasını istemesi sınıftaki öğrenciler arasında ayrımcılığa neden olabilmektedir. Örneğin:

Diğer sorun ise, benim çocuğum neden sonuç toplam değerlendirme sinavinda zaylf not alıyor gibi şikâyetlerdir. Bu şikâyeti olan veliler çocuklarının bilgi düzeyinin üstünde not beklemektedir (OY).

Bazı veliler çocuklarının puanlarının yüksek olması, kendi çocuğunun ön sırada oturması için sorun çıkarıyorlar (OV2).

Bazı velilerin çekingen davranarak okulla ilgili yaşadığı sorunu dile getirmemesi, mevcut sorunun devam etmesine ve okul-aile iş birliğinin sarsılmasına neden olabilir. Velilerin okulun herhangi bir olumsuz tepkisiyle karşılaşmamak için böyle davrandıkları düşünülebilir. Katılımcı görüşleri:

Bazı velilerim ise, ögretmenlerle ilgili sorunları olduğu halde bunu dile getirmiyor, şikâyetçi olmuyorlar. Bunun nedeni ise, çocuğunun puanının daha da kötü olmasından korkmalarıdır (DÖ1).

Genelde velilerin okulla ilgili sorunları oluyor ama toplantılarda veliler sorunları söylemiyorlar (DV4).

Velinin yüksek puan beklentisi, kendi aralarındaki sorunları okula yansıtmaları, çocuğunun hatasını kabullenmemesi ve okulla ilgili sorunları dile getirmemesi katılımcıların ortak görüşte oldukları sorunlardır. Velinin saldırgan tutum sergilemesi, çocuğunu anadilinden farklı bir sınıfa kaydettirmesi, öğrenci evrakını okuldan almaması, okulu bilgilendirmeden çocuğunu kendisiyle birlikte uzun süre yerleşim yeri dışında tutması, okulu suçlaması ve öğretmen seçmesi YD kodlu okulda; velinin çocuğunun sınıfını sıkça değiştirmesi, çocuğun yanında okul hakkında olumsuz konuşması, aralarındaki sorunu öğrenciye yansıtması, ayrımcılık yapması ve çocuğunun ön sırada oturması için sorun çıkarması OD kodlu okulda; velinin her şeyi okuldan beklemesi, gösterilen hoşgörüyü kötüye kullanması, okulu kabullenmemesi, öğretmeni şantaj etmesi ve okulla ilgili sorunları dile getirmemesi DD kodlu okulda saptanan veli kaynaklı sorunlardır.

Katılımcı görüşlerine göre, okul-aile iş birliğinde öğrencilerden kaynaklı sorunların da yaşandığı anlaşılmıştır. Öğrenci kaynaklı sorunlarla ilgili saptanmış bulgular Şekil 7’de sunulmuştur.

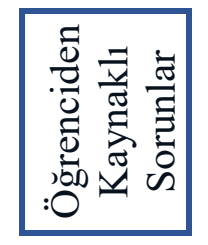

Öğretim ortamını bölme, öğreniminde başarısız olma, velisine yalan söyleme, okula formasız gelme, Mektepli Kitapçası'ndakı notu silme, Mektepli Kitapçası'na velisinin yerine imza atma ve okula akıllı telefon götürme

Şekil 7. Okul-Aile İş Birliğinde Öğrenciden Kaynaklı Sorunlar

Elde edilen görüşlerden öğretmen ve velilerin bazı öğrencilerin öğrenme ortamını bölmesinden yakındı̆̆ anlaşılmıştır. Öğrencinin olumsuz davranışları velisi ile ilişkilendirilmiştir. Katılımcı görüşlerine göre, tek veli tarafindan büyütülen öğrencilerle daha fazla sorun yaşanmaktadır. Örneğin:

İki velimle aynı sorunu yaşıyorum. Birinin eşi vefat etmiş, diğeri eşinden ayrılmıştır. Bu iki velinin çocuğu olumsuz davranışlara sahip ve ögrenme ortamını bölüyor... (OÖ2).

Büyük çocuğumun sinıfinda derste gürültü yapan, ders sürecini bozan ögrenciler var. Öğretmenimiz her zaman veli toplantısında onların velileriyle konuşuyor ama sonuç yoktur... Babası hep agresif davranışlar sergiliyor. Bu da çocuğu olumsuz etkiliyor (YV4).

Öğrencinin velisine yalan söylemesi öğretmen ve veli arasındaki iletişimi olumsuz etkileyen öğrenci kaynaklı bir sorundur. Örneğin:

Bir keresinde erkek öğrencimin yană̆ını sevgi belirtisi olarak hafifçe sıkmıştım. Öğrencim o gün bir arkadaşıyla kavga etmiş. Eve gittiğinde annesi yüzündeki morluğu sorduğunda öğretmenim yapmıs demişti. Velisi okula gelmişti. Veliye çocuğun yanağından hafif̧̧e makas aldı̆̆ımı, iz bırakacak bir şskilde sıkmadı̆̆ımı söylemiştim. Sonra çocukla konuştuğumuzda ailesine gerçeği söylemekten korktuğu için yalan söylediğini itiraf etti. O olaydan sonra ögrencimin başını bile okşamaktan çekiniyorum (DÖ2).

Öğrencinin Mektepli Kitapçası üzerinde olumsuz işlemler yapması okul ile aile arasındaki iletişimi engelleyen davranışlardır. Bu konuda elde edilmiş görüşler:

Bazen ögrenci Mektepli Kitapçası'na yazdı̆̆ım notu siliyor, veli de yazdığımı görmüyor (DÖ2).

Büyük çocuğumun derslerinde gerileme olduğu için düşük not almış ama Mektepli Kitapçası'nı bana göstermeden benim imzama benzer imza atmiştı (DV3).

Katılımcı görüşlerinde okul yönetiminin okula akıllı telefon götürülmemesi konusundaki uyarısını öğrencilerin dikkate almaması öğrenciler arasında soruna neden olmakta, bu sorun velilere de yansımaktadır. Örneğin: 
Toplantıda sinıf rehber ögrretmen okula akıllı telefon getirmenin yasak olduğunu söyledi. Ben de sinıf rehber öğretmen ile hemfikirim çünkü çocuklar birbirinin fotoğrafinı çekip dalga geçiyorlar (YV2).

Öğrencilerin öğretim ortamını bozması ve velisine yalan söylemesi, hem okul yöneticisi ve öğretmenin hem de velinin ortak görüşte oldukları sorunlardır. Öğrencinin okula akıllı telefon götürmesi YD kodlu okulda; Mektepli Kitapçası'na velisinin yerine öğrencinin imza atması ve Mektepli Kitapçası'ndakı notu silme DD kodlu okulda tespit edilen öğrenci kaynaklı sorunlardır.

\section{Okul-Aile İş Birliği Sorunlarının Çözüm Yolları}

Katılımcılara okul-aile iş birliğine ilişkin sorunları nasıl çözdüklerine dair soru sorulmasında amaç sorun çözümünde hangi sürecin izlenildiğini, sorun çözümünde okul yöneticileri ve öğretmenlerin ne kadar yeterli olduğunu ve velilerin sorun çözümüne nasıl katkı sağladığını belirlemektir. Okul-aile iş birliği sorunlarının çözümüne ilişkin elde edilmiş kodlamalar okulun ve velinin çözüm yolu kategorileri altında sınıflandırılmıştır. Çözüm yollarına ilişkin saptanmış bulgular Şekil 8'de sunulmuştur.

Karşılaşılan sorunları yöneticinin sakinliğini koruyarak çözmesi sorunun çözümüne katkı sağlayan önemli yönetici özelliklerindendir. Diğer katılımcılar gibi aşağıdaki katılımcının görüşünde de tarafların sorunu birbirleriyle konuşarak çözmesi en etkili yol olarak görülmektedir:

Velimiz okula agresif bir şekilde geldiğinde tabii ki biz onun gibi agresif tavir sergileyemeyiz. Biz yasalara uygun ve sakin bir şekilde veliyle konuşmaya çalışıyoruz. Bir kez soruyor, iki kez soruyor, beş kez soruyorsa biz de beş kez cevap veriyoruz (YY).

Yöneticinin öğrencilerin okula okul formasıla gelmemesi sorununu çözmek için, öğrencilerin giyim kuşamını kontrol altında tuttuğu, formasız öğrencilerle yüz yüze konuştuğu ve telefon aracıllğgyla iletişim kurarak velisini de bu konuda bilgilendirdiği anlaşılmıştır. Katılımcının görüşü:

Her sabah sırada dururken ögrencilerin kiyafetine dikkat ediyorum. Sik sik müdür yardımcılarımla tüm sinıfları dolaşıyoruz ve formayla gelmeyen ögrencileri odama çağırı konuşuyorum. Velisini de arayıp çocuğunun okula formayla gelmesi gerektiğini söylüyorum (YY).
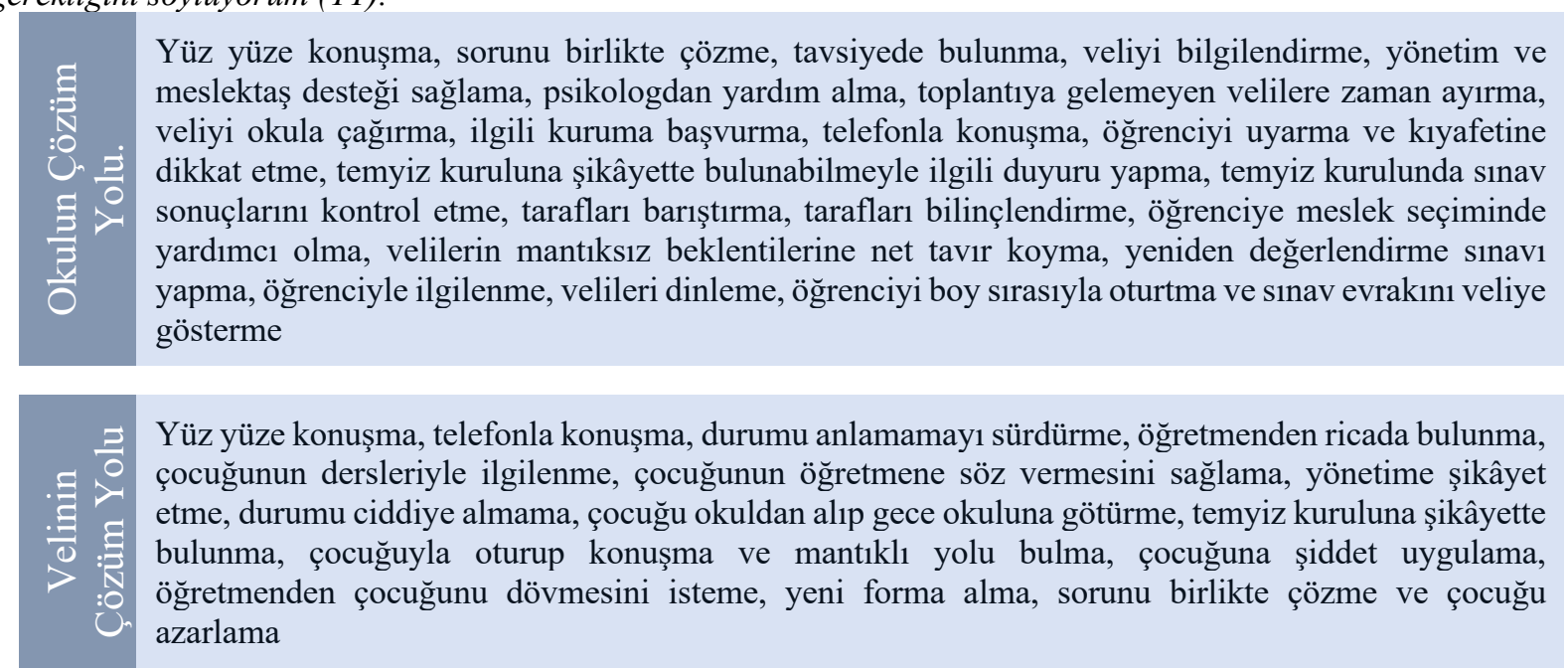

Şekil 8. Okul-Aile İş Birliği Sorunlarının Çözüm Yolları

Çözümü okulu aşan sorunlarda ilgili kurumların desteği alınarak sorun çözüme kavuşturulmaktadır. Bu konudaki katılımcı görüşü:

Öğrenciler uzun bir süre okula gelmediğinde gereken kurumları bilgilendiriyoruz. Velimiz bize haber vermeden çocukları okula getirmediğinde il eğitim müdürlüğ̈̈ne ve polise haber verdik. Anneye ulaşıldı ve çocukların okula gelmesi gerektiği söylenildi $(Y Y)$.

Öğrenci değerlendirme notuyla ilgili şikâyetlere temyiz kurulunda ${ }^{3}$ bakılarak sorunun çözülmesi objektif sorun çözme yolu olarak değerlendirilmektedir. $O Y$ 'nin görüşü:

Yüksek not beklentisinde olan velilerimize değerlendirme sinav sonucundan memnun olmadıkları zaman temyiz kuruluna şikâyette bulunabilmeleriyle ilgili duyuru yaptık. Şikâyette bulunan velilerin çocuklarının sinav sonuçların temyiz kurulunda yeniden kontrol ediyoruz $(O Y)$.

${ }^{3}$ Okul temyiz kurulu, sınav döneminde okulda sınav sonuçlarına ilişkin yapılan şikâyetlerle ilgilenmek için okullarda oluşturulan kuruldur. 
Öğretmenlerin sorunları çözerken meslektaşları, okul psikoloğu ve okul yönetimi tarafindan desteklenmesi öğretmenin sorun çözümünde tek başına olmadığını göstermektedir. Okullarda sorunların kolektif bir dayanışma sonucunda çözüldüğü anlaşılmıştır. Örneğin:

Sinıfta zorluk çıkaran öğrencilerimiz olduğunda, sorunu çözmek için okulumuzun psikoloğundan yardım alıyorum (YÖ1).

Okul-aile iş birliği konusunda karşılaștı̆̆ım sorunları çözmem de müdür, müdür yardımcımız hatta öğretmenlerimiz bana yardimcl oluyor (Ö̈2).

OÖ1, veli kaynaklı sorunu çözerken veli beklentilerinin değerlendirilerek ona göre yaklaşım sergilenmesi gerektiğiyle ilgili şu görüşte bulunmuştur:

Çocuğunun sınıfinı sı slk değiştiren veli benim sinıfima geldiğinde kendi kendime dedim ki, ben öyle bir şey yapmaliyım $k i$, bu sinıf değiştirme sorunu bitsin. İlk önce sinıf toplantısı yaptım ve tüm öğrencilerin benim için eşit olduğunu söyledim. Hiçbir velinin çocuklar arasında ayrımcıllk yapmam için bana gelmemesini istedim. Bunu yapmakla aslında o veliye ögrencilerle ilgili tavrımın ne olduğunu belirtmek istedim. Düşünüyorum ki, velilerin mantıklı beklentilerini olumlu karşılamaliyız. Mantıklı olmayan beklentilerine net tavrımızı koymamız gerekiyor (OÖ1).

Velilerin, çocuklarının öğreniminde başarısız olmasıyla ilgili sorunu çözerken okulun da desteğini aldıklarına dair görüşte bulunması, sorunların çözümünde okulun da yapıcı tutuma sahip olduğunu ortaya koymaktadır. Veli görüşleri aşağıda sunulmuş̧tur:

Çocuğum derslerini yaparken hep üzerinde durdum. Hep derslerini takip ettim. Öğretmenlerle gelip konuştum. Bu sene önceliğim çocuğumun notlarının iyileşmesidir. Bunun için sık sı öğretmenini arıyorum, çocuğun durumunu soruyorum (YV2).

Çocuğumun öğrenim durumunu iyileştirmek için okulda hocalar, evde ben çok sılkı iş birliği yaptık (DV3).

Öğrenciden kaynaklı sorunun çözümünde velinin çocuğunun öğretmene söz vermesini ve öğretmenden özür dilemesini sağlaması, velinin öğretmenin yanında olması ve çocuğun öğretmene saygılı davranması gerektiği görüşünü yansitmaktadır. Örneğin:

Çocuğumu öğretmeninin karşısına getirdim ve öğretmeninin karşsısında derslerini iyi yapacağııa dair söz verdirttim. Öğretmenleri de să̆ olsun, onunla daha fazla ilgileneceklerini söylediler (YV2).

Çocuğumun imzamı taklit ettiğini sağ olsun öğretmen fark etmiş, beni okula çağırmıştı. Çocuğumu azarlamıştım. Çocuğum hocadan da benden de özür diledi (DV3).

Bulgular, sorunların çözümünde hiçbir sorumluluk üstlenmek istemeyen ve öğrenciyi eski kuşakların benimsediği "eti senin kemiği benim" anlayışıyla tamamen öğretmene bırakan velilerin de bulunduğunu göstermektedir. Aşağıda bu velilerin görüşleri kendi ifadeleriyle sunulmuştur:

Elde ettiğim bilgilerden öğrencim yedinci sinıfta okuduğu halde çevrenin etkisi sonucunda sigaraya meyillidir. Bu durumu veliyle konuştum, veli çok çaresiz bir şekilde bana bakıyor. Benim bir şeyler yapmamı bekliyor. Bu durumda hatta veli resmiyeti birakip benden rica ediyor ki, lütfen bu durumu çözün (DÖ2).

Öğretim ortamını bölen öğrencinin annesiyle konuştuğumda bana diyor ki: "Öğretmenim ben onunla baş edemiyorum, siz onunla ilgilenin. Hocam, ne istersiniz yapın ister dövün ister öldürün." diyorlar. Ben onu anlamiyorum. Bir veli nasll kendi çocuğuyla baş edemez? Bana göre veli sadece kendi sorumluluğunu taşımak istemiyor. O kendisi de biliyor, çocuğu dövmek gibi hakkimız yoktur, sadece başından savmak için öyle söylüyor (OÖ2).

Aşağıda belirtilen yöneticinin görüşünden, velinin soruna yaklaşımının sorunu göz ardı ederek, çözümü zamana bırakmak olduğu anlaşılmaktadır:

Slk sık okula gelmeyen öğrencimizin velisini okula çağırı konuştum. Böyle devam ederse çocuğun sinıfta kalacağını söyledim. Anne de çocuğunu okuldan allp gece okuluna götürdü. Anne problemi böyle çözmüss oldu (YY).

DD kodlu okulun web sitesinden, okul yönetimi tarafindan gerçekleştirilen düzey belirleme değerlendirmesinde velilerin de öğretmenle birlikte sınıflarda gözlemci olarak bulunduğu tespit edilmiştir. Bu bulgu, değerlendirmenin objektif şekilde yapılması ve veli şikâyetinin oluşmaması için alınan proaktif bir önlem olarak değerlendirilebilir. Velilerin ders denetimine ve öğrenci değerlendirmesi sürecine katılımının sağlanması okul yönetiminin veli okul katılımına açık olduğunu göstermektedir.

Ders yapmayan öğretmenlerden yakınan veli sorunun çözümünü aşağıdaki ifadesiyle dile getirmiştir:

Bazı hocalar ders yapmadığında sinıf rehber öğretmenimize ve müdüre şikâyet ediyoruz. Onlar hemen tedbir allyorlar (OVI).

Katılımcıların okul-aile iş birliği sorunlarını çözmeyle ilgili ortak görüşleri yüz yüze ve telefonla konuşma, tavsiyede bulunma, veliyi bilgilendirme, sorunu birlikte çözme, veliyi okula çağırma ve öğrenciyi uyarmadır. Müdür yardımcısıyla birlikte tüm sınıfları dolaşma, öğrencilerin kıyafetine dikkat etme, öğrenciyi uyarma, öğrenciye meslek seçiminde yardımcı olma, yeniden değerlendirme sınavı yapma ve öğrenciyle ilgilenme okulun; çocuğu okuldan alıp gece okuluna götürme, çocuğuyla oturup konuşma ve mantıklı yolu bulma, çocuğuna şiddet uygulama ve yeni forma alma ise velinin YD kodlu okulda kullandığı çözüm yollarıdır. Temyiz kuruluna şikâyette bulunma hakkı konusunda duyuru yapma, temyiz kurulunda sınav sonuçlarını kontrol etme, tarafları barıştırma, velinin mantıksız beklentilerine 
net tavır koyma, öğrenciyi boy sırasıyla oturtma ve sınav evrakını veliye gösterme okulun; temyiz kuruluna şikâyette bulunma ve öğretmenden çocuğunu dövmesini isteme ise velinin OD kodlu okulda kullandığ 1 çözüm yollarıdır. DD kodlu okulun velisi ise, çocuğunu azarlayarak sorunu çözmektedir.

\section{Okul-Aile İş Birliğinin Paydaşlara Etkisi}

Okul-aile iş birliğinin paydaşlara etkisine ilişkin bulgular, olumlu ve olumsuz etkiler olmak üzere iki alt temada ele alınmıştır. Okul-aile iş birliğinin paydaşlara etkisi, Şekil 9'da artı ve eksi işaretleriyle simgelenerek sunulmuştur.

Mutluluk duyma, veli memnuniyeti, öğrenci başarısının artması, veli desteğini hissetme, okul gezilerinde velilerin kaynaşması, okulun itibarının artması, öğrenci davranışlarının düzelmesi, öğrencinin sosyalleşmesi, velinin aktif hale gelmesi ve ders dinleyen velinin ögretmenin takdirini kazanması
Sorun çözümünün zaman alması, destek alınamadığında istenilen sonuca ulaşamama, tükenme duygusu, okulun itibarının zarar görmesi ve velinin çocuğunu okuldan alması

Şekil 9. Okul-Aile İş Birliğinin Paydaşlara Etkisi

Bulgular, velilerin okulda gerçekleştirilen etkinliklere katılmaktan ve okulda karşılaştıkları davranışlardan mutlu ve hoşnut olduklarını göstermektedir. İş birliğinde yaşanan bu mutluluk ve hoşnutluk duygusu kelebek etkisi yaratabilecek güçtedir. Okuldaki olumlu ortam, öğrenci ve velinin okula aidiyet duygusunu artırma, bu olumlu yaklaşımların da öğretmen ve yöneticilere yansıma gizilgücü bulunmaktadır. Aşağıdaki katılımcı görüşleri de bunu ortaya koymaktadır:

Yaptığımız münazara, bilgi ve resim müsabakaları, bilgi ve spor olimpiyatları, müze ve tarihi mekânlara yapılan ziyaretler çocukların dünya görüşünü ve akademik başarısın olumlu yönde etkiliyor, onları yeni başarllar için daha da motive ediyor. Çocuğunun başarısını, mutluluğunu gören veli de mutlu oluyor. Çocuklara etkinliklerde rol almalarına göre başarı belgesi verildiğinde, bir fotoğraf çekildiğinde ögrrenciyle birlikte velisi de mutlu oluyor. Öğrencilerimizin başarısı ve velilerimizin olumlu dönütü müdürü ve beni mutlu ediyor (DÖ1).

Geçenlerde derslerini iyi öğrendikleri için öğretmen çocuklarımı sınıfin önünde başarı belgesiyle ödüllendirmişti. Bu onları çok sevindirmişti. Aslında bir kâğıt ama benim için çok değerli bir şey, çocuğum eve çok mutlu gelmişti. Evlatlarımın mutluluğu benim de mutluluğumdur (DV3).

Okula geldiğimde ister yönetim ister öğretmenler beni güler yüzle karşıllyorlar. Çocuğumla ilgili beni bilgilendiriyorlar. Bu da beni memnun ediyor. Bizim okula gelip çocuğumuzla ilgilenmemiz hem ögretmenin hem de müdürün hoşuna gidiyor (DV2).

Çocuklarım okulda oldukları zaman gözüm arkada kalmiyor. Güvende olduklarını bildiğim için çok rahat oluyorum. Okulda bu seneki eğitim ve öğretim koşulları daha iyidir. Okulda disiplinin olması ve öğrenciye olan yaklaşım bizi memnun ediyor (DV3).

DY aşağıdaki görüşünde veliyle doğru iş birliği kurmanın öğrenci başarısını artırdığına ve bu durumun okul itibarını da olumlu yönde etkilediğine dikkat çekmiştir:

Velilerle iş birliği okulu olumlu etkiliyor. Sağlam okul-aile iş birliği kurulduğunda her ü̧̧ taraf da kazanır. Veliyle başarılı iş birliği kurduğumuzda ögrencinin de başarısının arttı̆̆ın görüyorum. Dolayısıyla başarılı ögrencisi ve ögretmeni olan okulun da itibarı artmış olur (DY).

Okul-aile iş birliği öğrenci başarısını artırmakla birlikte, velinin de sosyal birey olarak aktif olmasını ve velilerin birbirine kaynaşmasını sağlamaktadır. Örneğin:

Önceleri çok da aktif veli değildim. Yani okul faaliyetlerini sadece izlemekle yetinirdim ama bu çocuğumla birlikte okulaile iş birliğine aktif şekilde katılmaya başladım. Bu iş birliği beni olumlu etkiliyor. Kendimi daha aktif biri olarak buldum (OVI).

Okul gezileri velileri birbirine yaklaştıriyor (OV4).

Yapllan uygulamalar sonucunda veliler okul faaliyetlerine katılmaya daha istekli oluyorlar (DÖ1).

Velinin çocuğuyla ilgilenmesi ve okul tarafından takdir edilmesi, öğrenci ve velinin yanı sıra öğretmenin iş doyumunu da olumlu etkilemektedir. Bu bulgunun sağlandığı veli görüşü de aşağıda sunulmuştur:

Ister okuldaki ortam ister benim ilgim çocuğumu da iyi etkiliyor. Çocuğum söylüyor ki, sen okula geldin, benim dersimi dinledin, ögretmenimin hoşuna gitti. Sen gittikten sonra sinıfta beni övdü. Dedi ki arkadaşınızın velisi gelip oturdu, sizin de velileriniz gelip derslerde otursun (DV2). 
Okul-aile iş birliğinde paydaşlardan birinin kendi sorumluluklarını doğru yerine getirmediğinde diğerlerini de olumsuz etkilediği tespit edilmiş bulgudur. Yönetici ve öğretmenler, okul-aile iş birliği sürecinde yaşanan sorunların olumsuz etkisiyle ilgili şu görüşlerde bulunmuşlardır:

Biz ĕgitimin-öğretimin kalitesi, ögrenci konulartyla ilgileniyoruz ve artı velilerin oluşturduğu sorunlar, bu bizi olumsuz etkiliyor (YY).

Bu iş birliğinde müdür yardımcılarımın ve ögretmenlerimin yeterince yardımcı olmaması beni olumsuz etkiliyor. Her şeyi tek başına yapmak zorunda kaliyorum (DY).

Öğrenciye bir birey olarak yaklaşılmayanda, aktif öğrenim koşulu oluşturulmayanda veli mutsuz oluyor ve müdüre şikâyette bulunuyor. Velilerin şikâyeti beni ve müdürü olumsuz etkiliyor, enerjimizi bu sorunları çözmeye harcıyoruz (DÖ1).

Tüm katılımcılara göre, okul-aile iş birliği mutluluk duygusu, veli memnuniyeti ve artan öğrenci başarısı yaratmaktadir.

\section{Tartışma, Sonuç ve Öneriler}

\section{Çalışmanın Sınırlılıkları ve Tartışma}

Nitel yöntemle yürütülen bu çalışmada, okul yöneticileri, öğretmen ve veli görüşlerine göre Bakü'de/Azerbaycan'da okul-aile iş birliğine ilişkin mevcut durum betimlenmeye çalışılmıştır. Çalışmanın verileri, 2019'un yaz ve güz döneminde Bakü’nün sosyoekonomik açıdan üç farklı ilçesindeki okullarda yüz yüze görüşme ve doküman analizi yöntemiyle toplanmıştır. Bu nedenle, bulgular çalışmaya katılmış üç okul yöneticisi, altı sınıf rehber öğretmeni ve 12 velinin görüşleri ve çalışmanın yürütüldüğü üç okulun resmi internet sitesinden 2019 yılına ait okul-aile iş birliğine ilişkin haberlerden elde edilen bilgilerle sınırlıdır. Çalışma verilerinin analizi sonucunda, okul-aile iş birliğinde paydaşlardan beklenen sorumluluklar, okul-aile iş birliği uygulamaları, okul-aile iş birliği sürecinde iletişim yolları, okul-aile iş birliğinin sorunları, okul-aile iş birliği sorunlarının çözümünde kullanılan yollar ve okul-aile iş birliğinin paydaşlara etkisi adlı temalar ortaya çıkmıştır.

İyi bir eğitim-öğretim ortamı oluşturma, öğrenciyle ilgilenme, veli ile iletişim kurarak veliyi sürekli bilgilendirme, öğrenciye birey olarak yaklaşma, iş birliğine açık olma okuldan beklenen sorumluluklarla ilgili saptanmış bulgulardır. Açıkalın (1989), Kaya ve Nartgün (2016) ile Kulak'ın (2020) çalışmasında da okuldan beklenen sorumluluklarla ilgili benzer bulgulara ulaşılmıştır. "Okul ve Veliler Arasındaki İş Birliği: Eğitim Sürecini Desteklemek" adlı rehber kitapta da okulun velilerle iş birliğine açık olmasına ve veliyi bilgilendirmesine vurgu yapılmıştır (Lifelong Learning Programme, 2020). Gerek bu çalışmada gerekse Kulak’ın (2020) bulgularında, öğrenci ailelerini yakından tanıma okuldan beklentilerden biri olarak belirlenmiştir. Bu beklentinin karşılanması öğrenci yönelimli çalışmalarda başarılı olmayı temin edebilir. Bu çalışmada çocuğunun eğitim-öğretimiyle ilgilenme ve okulda başlayan öğrenme sürecini evde devam ettirme velilerden beklenen en önemli sorumluluk olarak saptanmıştır. Kulak'ın (2020) çalışmasında da olumlu ve olumsuz durumlarda okulun ve öğretmenin yanında olma, duyarlı olma, sorumluluklarını bilme ve öğrencide olumlu davranışların oluşturulmasında okulu destekleme gibi yakın bulgulara ulaşılmıştır. Her iki çalışmada saptanan bu bulgular, okulun velinin manevi desteğine ilişkin beklentisini ortaya koymaktadır. Eğitim-öğretimiyle ilgilenmeyle birlikte, velinin çocuğuyla sağlıklı iletişim kurması da okulun veliden beklediği sorumluluklardan biridir. Benzeri bulgular, Babaoğlan ve Çelik (2018) ile Bilgen'in (2019) çalışmasında da gözlenmiştir. Okulla iletişimde olma, çocuğun doğru beslenmesini sağlama, çocuğa zaman ayırma ve çocuğun ders araç gereçlerini temin etme konusundaki bulgular da Bilgen'in (2019) çalışmasını desteklemektedir.

$\mathrm{Bu}$ çalışmada okul-aile iş birliğini güçlendirmek için toplantı yapılması, velinin okul etkinliklerine katılımının sağlanması, bireysel görüşme, açık kapı günü, ev ziyareti, seminer düzenleme, velilere takdir belgesi verme gibi uygulamalar gözlenmiştir. Benzer şekilde, Baker (1997), Yıldırım ve Dönmez (2008), Bæck (2010), Ratliffe ve Ponte (2018) ile diğer araştırmacılar tarafından yapılan çalışmalarda da okul etkinliklerine velilerin katılımının sağlanması bulgusuna ulaşılmıştır. Bu bulgular, veli katılımının tarafları birbirine yakınlaştırmakta ve velileri okula alıştırmakta etkili bir uygulama olduğunu göstermektedir. Delgado-Gaitan (1991), Baker (1997), Yıldırım ve Dönmez (2008), Hornby ve Witte (2010) de iş birliği sürecinde okulun velilerle bireysel olarak görüştüğü bulgusuna ulaşmışlardır. Bireysel görüşme, velinin belli bir konuda beklenti ve önerilerini öğrenmek, toplantıda konuşulması mümkün olmayan konuları tartışmak ve mevcut durumu net olarak görmek açısından okul-aile iş birliğinde yararlı bir uygulama olarak görülmektedir. Bu çalışmanın yanı sıra Yıldırım ve Dönmez (2008), Atakan (2010), Bæck (2010), Llamas ve Tuazon'un (2016) çalışmasında da veli toplantılarının yapıldığı bulgusu, veli toplantılarının velileri okulda yaşanan gelişmelerle ilgili bilgilendirmede ve belirli konularda karara katılımlarını sağlamada önemli bir okul-veli uygulaması olarak değerlendirilebilir. Hem Azerbaycan'da hem de diğer ülkelerde yapılan çalışmalarda açık kapı uygulamasıyla ilgili bulguya rastlanması, açık kapı uygulamasının velilerin okulun fiziksel koşulları ve öğretmenlerle tanışmasında önemli bir role sahip olduğunu göstermektedir. Okullarda velilere farklı konularda seminer verilmesi bulgusu, Yıldırım ve Dönmez (2008) ile Llamas ve Tuazon (2016) tarafından yürütülmüş çalışmalarda da ortaya çıkmıştır. Okullarda velilere 
seminer verilmesi, velilerin iş birliğini daha bilinçli şekilde yürütmesini sağlamaya hizmet eden uygulama olarak yorumlanabilir. Bu çalışmada saptanan ev ziyaretleri de Yıldırım ve Dönmez (2008) ile Llamas ve Tuazon'un (2016) çalışmasıyla örtüşen bir bulgudur. Her üç çalışmada gözlenen ev ziyaretleri, öğrencinin ailesini iyice tanımak ve evdeki öğrenme ortamını görmek açısından önemli bir uygulama olarak değerlendirilebilir. Bakü'deki okullarda velilerin de imecelere katılım sağlaması Ratliffe ve Ponte'nin (2018) çalışmasında da gözlemlenen bulgudur. Okullarda gerçekleştirilen imecelere öğretmen ve öğrencilerle birlikte velilerin de katılımının sağlanması paydaşların kaynaşmasına ve okul-aile iş birliğinin güçlenmesine katkı sağlayabilir.

Katılımcı görüşlerinden okulun en fazla tercih ettiği iletişim aracının telefon, velilerin ise Mektepli Kitapçası olduğu anlaşılmıştır. Araştırmasını Portekiz'in Vila Nova de Famalicão Belediyesi'ndeki bir okulda yürüten Abreu, Rocha ve Cota (2015), elektronik öğrenci kitapçı̆̆ının aile ve okul arasında önemli bir iletişim aracı olduğu bulgusuna ulaşırken, Azerbaycan'da en önemli iletişim aracı Mektepli Kitapçası'dır. Öğrencinin her dersle ilgili değerlendirme sonuçları ve final notları ile öğrenci davranışıyla ilgili bilgi ve öğretmen görüşleri, Elektronik öğrenci kitapçığı ve Mektepli Kitapçasında yer alan ortak özelliklerdir. Bu çalışmadaki gibi, Baker (1997), Yıldırım ve Dönmez (2008) ile Koyuncu'nun (2018) çalışmasında da telefonla görüşme okul-veli iş birliğinde iletişim yolu olarak gözlemlenmiştir. Bu çalışmayla birlikte, Delgado-Gaitan (1991) ile Hornby ve Witte'nin (2010) çalışmasında da velilerin katılımını sağlamak için davetiye mektubunun kullanıldığg anlaşılmıştır. Okullarda düzenlenen toplantı, seminer ve etkinliklere velilerin ilgilerini çekecek şekilde katılmalarını sağlamak için davetiye mektubu etkili bir iletişim aracıdır. Velilerin isteklerinin, beklentilerinin, eleştirilerinin ve önerilerinin öğrenilmesi açısından okul ve veli arasında iletişim aracı olarak şikâyet ve öneri kutusunun kullanılması, bu çalışmada ve diğer çalışmalarda saptanmış bulgudur (Cömert \& Güleç, 2004; Koyuncu, 2018). Okullarda yönetim duyurusunu ve düzenlenecek etkinliklerle ilgili bilgiyi paylaşmak için ilan levhasının okul-veli arasında iletişim aracı olarak kullanılması, bu çalışmadaki gibi Koyuncu'nun (2018) çalışmasında da gözlemlenen bulgudur. Okul ve veliler arasında iş birliğinin sağlanmasında sınıf veli komitesinin de aracılık ettiği anlaşılmıştır. Katılımcı görüşlerinden, sınıf veli komite başkanlarının daha çok sınıf rehber öğretmenin mesajlarını velilere ilettiği, sınıfın bayram etkinliklerinin düzenlenmesinde ve gezilerde öğretmenlere yardımcı olduğu, sınıfın kırtasiye ihtiyaçlarını karşılamak için velilerden para topladığı ve tüm velilerin toplanması mümkün olmadığ 1 durumlarda genel veli toplantılarına katıldığı anlaşılmıştır. Ancak saptanan bulgular, sınıf veli komite başkanlarının Genel Eğitim Okullarının Veli Komitesi Hakkında Yönetmelikte (2017) belirtilen hak ve sorumluluklardan haberleri olmadığını ortaya koymuştur.

Çalışmada öğretmenlerden kaynaklı sorunlarla ilgili saptanan bulgular, öğretmenlerin mesleki açıdan yetersiz olduğu ve görev bilincine sahip olmadığı sonucunu ortaya koymaktadır. Bozkurt, (2012) ve Keman'ın (2019) çalışmasında da öğretmenlerin mesleki açıdan yetersiz oluşuyla ilgili bulgulara ulaşılmıştır. Öğretmenin mesleki açıdan yetersizliği, verimli öğrenme ortamı oluşturmayı ve velilerle sağlıklı iletişim kurmayı olumsuz yönde etkileyen bir sorundur. Çalışmada öğretmenlerin görev bilincine sahip olmadığını gösteren bulgulara ulaşılması okul yönetiminin işini zorlaştıran, öğrenci ve veliyle iş birliğini olumsuz etkileyen, öğrenci ve velinin okula bağlılığını zayıflatan bir sorundur. Öğretmenlerin öğrenciler arasında ayrımcılık yapması, frekansı en yüksek olan bir bulgudur. Azerbaycan Eğitim Kanunu'nun (2009) 5. Maddesi ve Azerbaycan Anayasası'nın (1995) 42. Maddesi'nde her bir vatandaşın cinsiyet, ırk, dil, din, sosyal statü, etnik kökeni ve siyasi görüşüne bakılmaksızın eşit koşullarda eğitim alma hakkının olduğu belirtilmesine rağmen, devlet eğitim kurumunda çalışan öğretmenlerin öğrenciler arasında ayrımcılık yapması yasal ilkelere aykırı bir durumdur. Ayrıca öğretmenlerin bu davranışı onların Öğretmen Andı’nda belirtilen "Mesleki faaliyetimi yerine getirirken herhangi bir etik dışı davranış biçimine izin vermeyeceğim." ilkesini benimsemediğini de ortaya koyan bir sorundur. Okul-aile iş birliğinde okuldan kaynaklı yaşanan sorunlardan biri, okulun psikolojik hizmet verme açısından yetersiz oluşudur. Öğrenci sayısına bakılmaksızın (ister 800-1000 isterse 2000 olsun), okullarda sadece bir psikolog çalışmaktadır. Okullarda öğrencilerin yanı sıra velilerle iletişim sürecinde okul yönetimi ve öğretmenlerin de psikolog desteğine ihtiyacı bulunabilmektedir. Bir psikoloğun bu kadar kişiyle ilgilenmesi mümkün olmayan ve hizmetin kalitesini olumsuz etkileyen bir durumdur. Quluyeva (2021) tarafindan yapılan haber de bu bulguyu desteklemektedir. Çalışmada yöneticinin velilerle iş birliğine açık olmaması, okul yönetiminden kaynaklı bir sorun olarak belirlenmiştir. Bu konuda yapılan bazı çalışmalarda da benzer bir bulgu tespit edilmiştir (Lawson, 2003; Atayeter, 2004). Okul yönetiminin öğrencinin ilk eğitimini veren ve okulda başlanan öğrenme sürecini evde devam ettiren velilerle iş birliği yapmaya açık olmaması, okulun eğitim-öğretim faaliyetinde tek başına kalmasına ve okul başarısındaki düşüşe yol açabilir. Çalışmada saptanmış bulgular, bazı velilerin okulla iş birliğine açık olmadığını ve ihmalkâr olduğunu ortaya koymuştur. Okullarda velinin çocuğuna ilgi, şefkat göstermemesi, eğitimiyle ilgilenmemesi, çocukta öz güven kaybına, saldırgan davranışlara, okuldan soğumaya ve öğreniminde başarısız olmaya neden olabilecek veli kaynaklı sorunlardır. Diğer araştırmalarda da benzeri sorunların varlığına dikkat çekilmiştir (Gül, 2007; Bozkurt, 2012; Karataş \& Çakan, 2018). Çalışmada velinin öğretmene saldırgan tavır sergilemesi öğretmen motivasyonunu ve okul-veli iş birliğini olumsuz etkileyebilecek bir sorun olarak belirlenmiştir. Bu bulguya Özdemir ve diğerleri (2015) tarafından yapılan çalışmada da rastlanmıştır. Velinin çocuğunun sınıfını sıkça değiştirmesi yönetici, sınıf rehber 
öğretmeni ve veli tarafından belirtilen bir sorundur. Özcan (2014) ve Keman'ın (2019) çalışmasında da okullarda benzer sorunun yaşandığı anlaşılmıştır. Öğrencinin sınıfı ya da okulu değiştiğinde, belirli bir alışma ve uyum süresine gerek duyulmaktadır. Bu süre verilmediğinde öğrenci psikolojik sorunlar yaşayabilir (Çelik Özbeklik, 2018). Velinin çocuğunun sınıfını sıkça değiştirmesi, onun çocuk psikolojisi hakkında bilgi sahibi olmadığını ortaya koymaktadır. Çalışmada veli kaynaklı saptanan sorunlardan biri de velinin çocuğunu şımarık büyütmesidir. Bu sorun okulda olumsuz öğrenci davranışlarına neden olmaktadır. "Öğretmenlerin Bakış Açısıyla Eğitim-Öğretim Sorunları” adlı çalışmada da benzer bulguya ulaşılmıştır (Karataş \& Çakan, 2018). Öğretmen görüşlerinden, velilerin çocuklarının ön sırada oturması ve yüksek puan için baskı yaptıkları anlaşılmıştır. Genellikle görme sorunu olan veya dikkat eksikliği yaşayan öğrenciler ön sırada oturtulur. Velinin çocuğunun ön sırada oturması için 1srarcı olması, öğretmenin işine müdahale olarak değerlendirilmektedir. Özcan (2014) da velilerin öğrenciye yüksek not verilmesi ve oturulacak yerle ilgili okuldan beklentileri karşılanmadığında okul yönetimini üst makamlara şikâyet ettiklerini saptamıştır. Velinin toplantılara katılmaması, öğretmen seçmesi, çocuğunun hatasını kabullenmemesi ve okulu suçlaması Azerbaycanlı velilerle ilgili saptanan sorunlardır. Keman (2019), okul yöneticilerinin sınıf toplantılarına katılmama, suçlayıcı ve hesap sorucu tavırlar sergileme, çocuklarının haksız olduğu durumlarda aşırı savunma ve itiraz etme, sınıf ve öğretmen değişikliği taleplerinde bulunma gibi veli kaynaklı sorunlardan yakındığını ortaya koymuştur. Gerek bu çalışmanın gerekse Keman'ın (2019) bulguları, velilerin okul-aile iş birliğine bilinçli şekilde yaklaşmadığını göstermektedir. Baker (1997), velinin bir sorunu iletmek ve tartışmak için okula geldiğinde, okul tarafından hoş karşılanmadığı ve gerek kendisinin gerekse çocuğunun olumsuz tepkiyle karşılaştığı bulgusuna ulaşmıştır. Azerbaycanlı velilerin de böyle bir durumla karşılaşmamak için okulla ilgili sorunları dile getirmedikleri düşünülmektedir. Çalışmada bazı velilerin her şeyi okuldan beklemesi, aslında çocuklarının eğitimiyle uğraşmak istemediklerini akla getirmektedir. Georgiou (1996) ve Keman (2019) da benzeri bulgulara ulaşmışlardır. Bu çalışma ile Erkan, Uludağ ve Dereli'nin (2016) bulguları, tek başına çocuk yetiştiren velilerin çocuğuyla yeterince ilgilenemediği sonucunu ortaya koymaktadır. Ayrıca okulda öğrenciden kaynaklı sorunların genellikle tek velili öğrencilerle yaşandığını göstermektedir. Bu çalışmanın bulguları (okula forması gelme, velisine yalan söyleme ve okula akıllı telefon götürme), Gökyer ve Doğan (2016) ile Keman'ın (2019) bulgularıyla tutarlıdır. Öğrencilerin öğrenme ortamını bölen davranışlar sergilemesi de alanyazında da saptanan başka bir bulgudur (Çetin, 2013; Medikoğlu \& Dalaman, 2018; Özer, Bozkurt, \& Tuncay, 2014). Okullarda bu sorunun yaşanması diğer öğrencilerin öğrenme sürecini engellemekle birlikte öğretmen motivasyonunu da olumsuz yönde etkilemektedir. Çalışmada öğrencinin öğreniminde başarısız olması, veli ve öğretmeni endişelendiren öğrenci kaynaklı bir sorun olarak saptanmıştır. Katılımcı okul müdürleri, öğrencilerin akademik açıdan yetersiz oluşunu en önemli öğrenci kaynaklı sorun olarak belirtmişlerdir (Dağlı \& Han, 2017).

Paydaşların yüz yüze görüşerek ve birbirlerini destekleyerek sorunları çözmeleri, okul-aile iş birliğini güçlendiren çözüm yolu olarak değerlendirilebilir. Diğer çalışmalarda da benzer şekilde sorunları yüz yüze konuşarak çözmenin en etkili yol olduğu belirlenmiştir (Delgado-Gaitan, 1991; Türnüklü, Şahin, \& Öztürk, 2002; Atıcı \& Çekici, 2009; Hornby \& Witte, 2010; Gündüz \& Konuk, 2016; Yumşak \& Balc1, 2018; Tingley, tarih yok). Yaşanan sorunların birlikte çözülmesi, paydaşların sorunun çözümünde ilgili olduğunu gösteren bir bulgudur. Türnüklü, Şahin, ve Öztürk (2002) ile Atıcı ve Çekici (2009) de sorunların birlikte çözüldüğünü saptamışlardır. Azerbaycanlı yönetici ve öğretmenler öğrenci kaynaklı sorunların (okula formasız gelme, velisine yalan söyleme ve okula akıllı telefon götürme) çözümünde, olumsuz davranışları için öğrencileri diğer çalışmalardaki gibi (Türnüklü, Şahin, \& Öztürk, 2002; Atıc1 \& Çekici, 2009; Özer, Bozkurt, \& Tuncay, 2014; Gündüz \& Konuk, 2016; Medikoğlu \& Dalaman, 2018; Yumşak \& Balc1, 2018) uyarmaktadırlar. Keman'ın (2019) bulguları, Azerbaycan'da okul-aile iş birliği sürecinde kullanılan çözüm yolları (veliyi okula çağırma, telefonla konuşma, veliyi bilgilendirme, okulu aşan sorunlarda ilgili kuruma başvurma, velilerin mantıksız beklentilerine net tavır koyma) ile benzerlik göstermektedir. Türnüklü, Şahin ve Öztürk (2002) ile Gül'ün (2007) bulgularında rastlanan, velilerin durumu ciddiye almaması, öğretmenden çocuğunu dövmesini istemesi, çocuğu azarlaması ve çocuğuna şiddet uygulaması gibi iyi sonuç doğurmayacak çözüm yollarına Azerbaycanlı velilerin de başvurdukları anlaşılmıştır. Azerbaycan okullarında bazı sorunlar psikologdan yardım almakla çözülürken, Türkiye'de de karşılaşılan sorunlar rehberlik servisine yönlendirme, rehber öğretmene iletme ve rehber öğretmenle görüşme yoluyla çözülmektedir (Türnüklü, Şahin, \& Öztürk, 2002; Urun \& Gökçe, 2015; Gündüz \& Konuk, 2016; Medikoğlu \& Dalaman, 2018; Yumşak \& Balc1, 2018; Keman, 2019).

Çalışmada, okul ile ailenin iş birliğinden paydaşların genellikle mutlu ve hoşnut oldukları ortaya çıkmıştır. İş birliği sürecinde okulda etkinliklerin gerçekleştirilmesi, velilerin okul faaliyetine katılımının sağlanması, öğrenci ve velilerin takdir edilmesi paydaşları mutlu etmektedir. Ok'un (2016) çalışmasında da veli görüşlerinden okul-aile iş birliğinin çocuk ve aileleri mutlu ettiği, çocuklarına ve kendilerine katkı sağladığı anlaşılmıştır. Bu çalışmadaki gibi diğer çalışmalarda da öğretmen ve velilerin iş birliği yapmasının öğrenci başarısını artırdığı tespit edilmiştir (Vahedi, 2010; Learning Liftoff, 2015; Biramo, G/Silase, \& Koyra, 2017). İş birliği, öğrenci başarısını artırmanın yanı sıra öğrencinin sosyalleşmesi, velinin daha aktif hale gelmesi, okulun itibarının artması ve veli desteğinin hissedilmesinde etkili olmaktadır. Topal, Erdem ve Dal (2013) da okul aile iş birliğinin öğretmenlerin öğrencileri tanımasında, velilerin 
çocuklarının gelişimini gözlemlemelerinde etkili olduğunu saptamışlardır. İş birliği sonucunda öğrenciler de daha başarılı ve okulu daha çok sevme eğiliminde olabilmektedirler (Learning Liftoff, 2015). Bu çalışmadaki gibi, Yıldırım ve Dönmez (2008) de okul-aile iş birliğinin öğrenci başarısını olumlu yönde etkilediği, özgüvenini artırdığı, sorumluluk duygusunu geliştirdiği, okulu benimsemesi, mutlu olması ve güdülenmesini sağladığı bulgusuna ulaşmışlardır. Mewezino'nun (2010) veli katılımının öğretmenlerin sınıflarında daha etkili olmalarına yardımcı olduğu, okuldaki gelişmeleri etkilediği ve öğrenci başarısını artırdığına ilişkin bulguları, bu çalışmanın sonuçlarıyla tutarlılık göstermektedir. Argon ve Kıyıcı (2012) ile Lasater (2016) tarafından bildirilen okul-aile iş birliği sorunlarının olumsuz etkileri, bu çalışmada da veliden destek alınamadığında istenilen sonuca ulaşamama, öğretmenlerin tükenme duygusu yaşaması, velinin çocuğunu okuldan alması, okulun itibarının zarar görmesi biçiminde ortaya çıkmıştır.

\section{Sonuç ve Öneriler}

$\mathrm{Bu}$ çalışmada, sağliklı okul aile iş birliği için gerek okulun gerekse velinin sorumluluklarına ilişkin beklentiler ortaya konmuştur. İş birliği sürecinde taraflar birlikte hareket ederek eşit katkı sağlamalıdır. Okul-aile iş birliğini sağlamak için okullarda öğrenci, veli ve öğretmen odaklı uygulamalar gerçekleştirilmektedir. Bu uygulamalar bilgilendirici, bilinçlendirici, kaynaştırıcı, katılımı sağlayıcı ve güdüleyici özelliklere sahiptir. Okul veli, veli okul ile iletişim kurmak için farklı iletişim araç ve kaynaklarından yararlanmaktadır. Bakü'de okul-aile iş birliği sürecinde paydaşlar kendi sorumluluklarını gereken şekilde yerine getirmediği için okuldan, veliden ve öğrenciden kaynaklı sorunlar yaşanmakta ve genellikle çözüme kavuşturulmaktadır. Sorunların çözümünde okul daha aktif olmakla birlikte büyük ölçüde veli desteğini de alabilmektedir. İş birliği sürecinde paydaşlar üzerinde olumlu ve olumsuz birtakım etkiler ortaya çıkmaktadır. Bu çalışmada, katılımcı veliler iş birliğinin sadece olumlu etkisini yansıtırken, yönetici ve öğretmenler gerek olumlu gerekse olumsuz etkilere dikkat çekmiştir. Çalışmaya katılan okullara ilişkin tüm bulgular dikkate alındığında da DD kodlu okulun en fazla iş birliği sorunu yaşayan, ancak aynı zamanda veli katılımını sağlamada daha aktif performans gösteren kurum olduğu sonucuna varılmıştır.

Nitel yöntemle yürütülmüş olması nedeniyle, kuşkusuz çalışma sonuçları tüm Azerbaycan okullarına genellenemez. Ancak çalışma bulgularının özelde çalışma grubunda yer alan okullar, genelde Azerbaycan eğitim yetkilileri için bir farkındalık yaratma gizilgücüne sahip olduğu düşünülmektedir. Çalışmanın sınırlılıkları göz ardı edilmeden politika yapıcılara, uygulayıcı ve araştırmacılara aşağıdaki önerilerde bulunulabilir:

1. Okullarda sadece bir psikoloğun bulunduğu ve ailelerle en çok iletişimde olan kurumun okul olduğu dikkate alınırsa, velilerle daha sağlıkı bir iletişim kurarak oluşabilecek sorunları önlemek için okullarda aile danışmanlığı hizmetinin verilmesi düşünülebilir.

2. Okullarda öğrenci başarısızlığı hem velileri hem de öğretmenleri endişelendirdiği ve öğrenci başarısını artırmak okulun en önemli önceliği olduğu için okullarda öğrenci koçluğu hizmeti verilebilir.

3. Azerbaycan'da okul-veli iş birliğinin daha sağlıklı ve displinli bir şekilde yürütülmesi için 1994 yılında yürürlüğe konmuş olan “Genel Eğitim Okullarının Veli Komitesi Hakkında Yönetmelik”te düzenlemeler yapılabilir.

4. Mektepli Kitapçası konusunda yaşanan sorunların çözümü ve karşılıklı iletişimin sağlanması için bir mobil uygulama geliştirilebilir.

5. Yönetici ve öğretmenler için, okul-aile iş birliğinde yeni yaklaşımların sunulabileceği ve katılımcıların etkileşim içinde olabileceği seminerler düzenlenerek bu konudaki yeterlikleri geliştirilebilir.

6. Okul etkinliklerine daha fazla velinin katılımını sağlamak için eğitim [terbiye, teşkilati] işlerinden sorumlu müdür yardımcısı, okulda düzenlenecek etkinlikler, toplantılar, seminer ve benzeri uygulamalarla ilgili aylık ebroşürler hazırlayarak önceki ayın son on günlüğünde okulun internet sitesinde ve sosyal medya araçlarında paylaşabilir.

7. Velilerin çocuklarına daha bilinçli şekilde yaklaşımını temin etmek için okul psikoloğu tarafından çocuklara yaklaşım ve çocuk davranışları konusunda kısa ve anlaşılabilir şekilde bilinçlendirici özelliğe sahip e-bültenler hazırlanarak okulun internet sitesinde ve sosyal medya sayfasında paylaşılabilir. Ayrıca tüm velilere ulaşmak için bu bültenler sınıf veli komite başkanlarına gönderilerek sınıf velilerinin sosyal medya gruplarında paylaşılması sağlanabilir.

8. Sınıf rehber öğretmeni öğrenciyi ve ailesini tanımak için planlı bir şekilde ev ziyaretleri yapabilir. Özel durumlarda sınıf rehber öğretmenine destek olmak için okul psikoloğu da öğretmenle birlikte ev ziyaretlerinde bulunabilir.

9. Okul veli komite başkanına ve sınıf veli komite başkanlarına "Genel Eğitim Okullarının Veli Komitesi Hakkında Yönetmelik”te belirtilmiş hak ve sorumluluklar doğrultusunda bilgilendirme yapılarak sorunların çözümünde aktif rol almaları sağlanabilir. 
10. Konuya ilgi duyan araştırmacılar, farklı desenlerde ve değişik ülkelerde benzer çalışmalar yapabilirler. Bu çalışma nitel desende yürütülmüştür. Genellenebilir nitelikte ve daha kapsamlı karşılaştırmalı çalışmalar yapılması da düşünülebilir.

\section{Araştırmacıların Katkı Oranı}

Yazarlar çalışmaya eşit oranda katkı sunmuşlardır.

\section{Destek ve Teşekkür}

Yazarlar çalışma için herhangi bir finansal destek almamışlardır.

\section{Çıkar Çatışması}

Yazarlar çalışmada herhangi bir çıkar çatışmasının bulunmadığını beyan etmişlerdir.

\section{Kaynakça / References}

Abreu, A., Rocha, Á., \& Cota, M. P. (2015). Electronic booklet: School-family collaboration in digital environments. International Journal of Information and Communication Technology Education, 11(4), 97-108. doi:10.4018/IJICTE.2015100107

Açıkalın, A. (1989). Özel ve devlet liselerinde veli beklentilerinin örgütsel ve yönetsel boyutları. Hacettepe Üniversitesi Eğitim Fakültesi Dergisi, 4(4), 85-91.

Argon, T., \& Kıyıcı, C. (2012). İlköğretim kurumlarında ailelerin eğitim sürecine katılımlarına yönelik öğretmen görüşleri. Dicle Üniversitesi Ziya Gökalp Eğitim Fakültesi Dergisi(19), 80-95.

Atakan, H. (2010). Okul öncesi eğitiminde aile katılımı çalışmalarının öğretmen ve ebeveyn görüşlerine göre değerlendirilmesi. (Yüksek Lisans Tezi). Yükseköğretim Kurulu Ulusal Tez Merkezi'nden edinilmiştir. (Tez No: 308976).

Atayeter, H. (2004). Illköğretim okullarında okul-aile işbirliği (Diyarbakır il örneği). (Yüksek Lisans Tezi). Yükseköğretim Kurulu Ulusal Tez Merkezi'nden edinilmiştir. (Tez No: 146376).

Atıc1, M., \& Çekici, F. (2009). Ortaöğretimdeki öğretmen ve öğrencilerin istenmeyen davranışlarla baş etme konusundaki görüşlerinin karşılaştırılması. Kuram ve Uygulamada Eğitim Yönetimi, 15(60), 495-522.

Atmaca, T., \& Öntaş, T. (2014). Velilerin öğretmenlere uyguladığ1 şiddete yönelik nitel bir araştırma. Anadolu Eğitim Liderliği ve Ögretim Dergisi, 2(1), 47-62.

Azərbaycan Respublikasının Konstitusiyası. (1995, Noyabr 27). Azərbaycan Respublikasının Әdliyyə Nazirliyi Normativ Hüquqi Aktların Vahid İnternet Elektron Bazası: http:/www.e-qanun.az/framework/897 adresinden alınd1

Azərbaycan Respublikasının Təhsil haqqında Qanunu. (2009, iyun 19). Azərbaycan Respublikasının Odliyyə Nazirliyi Normativ Hüquqi Aktların Vahid İnternet Elektron Bazası: http://www.eqanun.az/alpidata/framework/data/18/c_f_18343.htm adresinden alındı

Babaoğlan, E., \& Çelik, E. (2018). İdeal öğrenci velisi üzerine nitel bir çalışma. E-Uluslararası Eŭitim Araştırmaları Dergisi, 9(1), 51-65. doi:10.19160/ijer.370497

Bæck, U.-D. K. (2010). Parental involvement practices in formalized home-school cooperation. Scandinavian Journal of Educational Research, 54(6), 549-563. doi:10.1080/00313831.2010.522845

Baker, A. (1997). Improving parent involvement programs and practice: A qualitative study of parent perceptions. School Community Journal, 7(1), 127-153. 
Bayar, A., \& Bolat, H. (2020). Velilerin öğretmenlere öğretmenlik mesleğini öğretmeye çalışması. Journal of Social, Humanities and Administrative Sciences , 6(31), 1523-1534. doi:10.31589/JOSHAS.388

Bilgen, K. (2019). The rights and responsibilities of parents according to the views of teachers. Asian Journal of Education and Training, 5(1), 121-133. doi:10.20448/journal.522.2019.51.121.133

Biramo, Y. B., G/Silase, B. M., \& Koyra, H. C. (2017). The relationship between parental involvement and children's academic achievement in alternative basic education centers and regular primary first cycle school of Hamer Woreda, South Omo Zone, Ethiopia. International Journal of Current Research, 9(7), 54201-24209.

Bozkurt, S. (2012). Okul müdürlerinin okul yönetiminde karşılaştı̆ı sorunlar. Gaziantep Üniversitesi Sosyal Bilimler Dergisi, 11(2), 349 -368.

Çelik Özbeklik, S. (2018, eylül 13). Okul değişimi çocuğu nasıl etkiler? HThayat.haberturk: https:/hthayat.haberturk.com/anne-baba/egitim/haber/1002812-okul-degisimi-cocugu-nasil-etkiler adresinden alınd1

Çelik, H., Baykal, N., \& Kılıç Memur, H. (2020). Nitel veri analizi ve temel ilkeleri. Eğitimde Nitel Araştırmalar Dergisi, 8(1), 379-406. doi:0.14689/issn.2148-2624.1.8c.1s.16m

Çetin, B. (2013). Sınıfta istenmeyen öğrenci davranışlarıyla ilgili sınıf öğretmenlerinin karşılaştıkları sorunlar ve çözüm önerileri. Ahi Evran Üniversitesi Kırşehir Eğitim Fakültesi Dergisi (KEFAD), 14(1), 255-269.

Cömert, D., \& Güleç, H. (2004). Okulöncesi eğitim kurumlarında aile katılımının önemi: Öğretmen-aile-çocuk ve kurum. Afyon Kocatepe Üniversitesi Sosyal Bilimler Dergisi, 6(1), 131-145.

Creswell, J., \& Creswell, J. (2014). Research design: Qualitative, quantitative and mixed methods approaches (4th ed.). Thousand Oaks, California: SAGE.

Dağl1, A., \& Han, B. (2017). Okul Müdürlerinin Görüşlerine Göre Diyarbakır İli Eğitim Sorunları ve Çözüm Önerileri. Dicle Üniversitesi Ziya Gökalp Ĕ̈itim Fakültesi Dergisi(32), 892-904. doi:10.14582/DUZGEF.1868

Delgado-Gaitan, C. (1991). Involving parents in the schools: A process of empowerment. American Journal of Education, 100(1), 20-46.

Dünyamalıyeva, V. (2017, noyabr 21). Ümumtəhsil məktəbinin valideyn komitəsi haqqında Osasnamə. Aztəhsil: https://aztehsil.com/news/4506-mumthsil-mktbinin-valideyn-komitsi-haqqnda-sasnam.html adresinden alınd1

Epstein, J. (2015). Engaging families in partnership programs to promote student success: $Q \& A$ for Dr. Joyce L. Epstein. REL Mid-Atlantic educator effectiveness webinar series. Regional Educational Laboratory MidAtlantic.

Epstein, J., Sanders, M., Simon, B., Salinas, K., Jansorn , N., \& Van Voorhis, F. (2002). School, family, and community partnerships: Your handbook for Action ( 2 nd ed.). Thousand Oaks: Corwin Press.

Erkan, S., Uludağ, G., \& Dereli, F. (2016). Okul öncesi öğretmenleri, okul yöneticileri ve ebeveynlerin aile katılımına ilişkin algılarının incelenmesi. Ahi Evran Üniversitesi Kırşehir Eğitim Fakültesi Dergisi, 17(1), 221-240.

Georgiou, S. N. (1996). Parental involvement in Cyprus. International Journal of Educational Research, 25(1), 33-43.

Gökyer, N., \& Doğan, B. (2016). İstenmeyen öğrenci davranışları ve nedenlerine ilişkin yönetici ve öğretmen görüşleri. Firat Üniversitesi Sosyal Bilimler Dergisi, 26(1), 93-105. 
Goodman, M. (2015). Future crimes: Everything is connected, everyone is vulnerable and what we can do about it. New York: Doubleday.

Gül, E. (2007). Eğitimde çocuk başarısı için okul aile işbirliği. (Yüksek Lisans Tezi). Yükseköğretim Kurulu Ulusal Tez Merkezi'nden edinilmiştir. (Tez No: 241827).

Gündüz, H., \& Konuk, S. (2016). İlkokul öğretmenlerin karşılaştıkları istenmeyen davranışlar ile baş etme stratejileri. Yuldiz Journal of Educational Research, 1(1), 37-54.

Gündüz, M. (2015). İlk ve orta öğretimde uygulanan şiddet olaylarına öğretmen adayı öğrencilerin anlatılarından bakmak. Marmara Üniversitesi Atatürk Eğitim Fakültesi Eğitim Bilimleri Dergisi, 42(42), 261-276. doi:10.15285/ebd.94519

Hornby, G. (2011). Parental involvement in childhood education: Building effective school-family partnerships. New York: Springer.

Hornby, G., \& Witte, C. (2010). Parental involvement in secondary schools in New Zealand: Implications for school psychologists. School Psychology International, 31(5), 495-508. doi:10.1177/0143034310382611

İbrahimova, C. (2019, aprel 09). İntihar etdiyi deyilan Elina Hactyevanın anası: "Bu işdə əli olan hər kəsdən şikayət etmişik". BBC News Azərbaycanca: https://www.bbc.com/azeri/azerbaijan-47868971 adresinden alındı

Karataş, K., \& Çakan, S. (2018). Öğretmenlerin bakış açısıyla eğitim-öğretim sorunları: Bismil ilçesi örneği. İlköğretim Online, 17(2), 834-847. doi:10.17051/ilkonline.2018.419313

Kaya, A., \& Nartgün, S. (2016). Özel okul velilerinin beklentileri doğrultusunda okul imaji oluşturma. Eğitim ve Ögretim Araştırmaları Dergisi, 5(2), 153-167.

Keman, F. Y. (2019). Göreve yeni başlayan okul yöneticilerinin karşılaştıkları sorunlar ve çözüm önerileri. (Yüksek Lisans Tezi). Yükseköğretim Kurulu Ulusal Tez Merkezi’nden edinilmiştir. (Tez No: 541383).

Khajehpoura, M., \& Ghazvini, S. D. (2011). The role of parental involvement affect in children's academic performance. Procedia Social and Behavioral Sciences, 15, 1204-1208. doi:10.1016/j.sbspro.2011.03.263

Koyuncu, M. Ş. (2018). Okul öncesi eğitimde aile iletişim etkinliklerine yönelik öğretmen ve yönetici bakış açıları. Uluslararası Sosyal Araştırmalar Dergisi, 11(55), 670-684. doi:10.17719/jisr.20185537238

Kulak, R. (2020). Okul-veli işbirliği, sorunları ve çözüm önerileri. Journal of Social, Humanities and Administrative Sciences, 6(31), 1628-1640. doi:10.31589/JOSHAS.416

Lasater, K. (2016). Parent-teacher conflict related to student abilities: The impact on students and the family-school partnership. School Community Journal, 26(2), 237-262.

Lawson, M. A. (2003). School-family relations in context: Parent and teacher perceptions of parent involvement. Urban Education, 38(1), 77-133. doi:10.1177/0042085902238687

Learning Liftoff. (2015, 05 27). How parental involvement benefits the entire educational process. Learning Liftoff: https://www.learningliftoff.com/how-parental-involvement-benefits-the-entire-educational-process/ adresinden alınd 1

Lifelong Learning Programme. (2020, March 10 indirildi). Projekt Comenius Regio: "Education in areas characterized by a lack of access to infrastructure and highly qualified jobs in the context of the Europe 2020 strategy" 
Cooperation between school and parents. Supporting the educational process. Zespół Szkół im. Wł. Szybińskiego w Cieszynie: https://www.szybinski.cieszyn.pl/szybinski_new/sites/default/files/wsp\%C3\%B3\%C5\%82praca\%20z\%20rod zicami\%20-\%20regio\%20handout_ENGLISH_0.pdf adresinden alındı

Llamas, A. V., \& Tuazon, A. P. (2016). School practices in parental involvement, its expected results \& barriers in public secondary schools. International Journal of Educational Science and Research, 6(1), 59-78.

Meador, D. (2019, July 30). How teachers should deal with difficult parents. ThoughtCo: thoughtco.com/principalperspective-on-difficult-parents-3194556 adresinden alındı

Medikoğlu, O., \& Dalaman, O. (2018). Öğretmenlerinin derste karşılaştıkları istenmeyen öğrenci davranışları ve bu davranışlara yönelik çözüm stratejileriyle ilgili öğretmen görüşlerinin belirlenmesi. Eğitim Kuram ve Uygulama Araştırmaları Dergisi, 4(1), 20-32.

Mewezino, A. (2010). Improving schools by improving parental involvement. (Yüksek Lisans Tezi). University of Dayton, Ohio.

Nəbiyeva, A. (2019, iyun 19). Bizdə bu xidmət pul ylğmaqla məhdudlaşır. AZADİNFORM: https://azadinform.az/az/gundem/226274/bizde-bu-xidmet-pul-yimaqla-mehdudlasir/ adresinden alınd1

Ok, S. (2016). Öğretmen ve ailelere göre okul öncesi eğitimde okul-aile işbirliğinin önemi. İstanbul Aydın Üniversitesi Dergisi, 8(32), 61-79.

Oskay, G. (1990). Ana-baba ve arkadaş gruplarının ergenler üzerindeki etkisi. Hacettepe Üniversitesi Edebiyat Fakültesi Dergisi, 7(1-2), 65-86.

Özcan, K. (2014). Çevresel baskı gruplarının okul yönetimine etkileri (Adıyaman ili örneği). e-International Journal of Educational Research, 5(1), 88-113.

Özdemir, M., Civelek, Ş., Çetin, Y. E., Karapınar, N., \& Özel, D. (2015). Öğretmenlerin eğitimsel çevresel ve sosyal sorunları (Şırnak ili örneği). Dicle Üniversitesi Ziya Gökalp Eğitim Fakültesi Dergisi(26), 163-181. doi:10.14582/DUZGEF.609

Özer, B., Bozkurt, N., \& Tuncay, A. (2014). İstenmeyen öğrenci davranışları ve öğretmenlerin kullandıkları başa çıkma stratejileri. Turkish Journal of Educational Studies, 1(2), 152-189.

Porsuk, A., \& Kunt, M. (2012). Denizli merkez ilköğretim okullarındaki okul aile ilişkilerinde karşılaşılan sorunlar üzerine yönetici görüşleri. Pamukkale Üniversitesi Eğitim Fakültesi Dergisi, 31(31), 203-218.

Quluyeva, Z. (2021, mart 13). Onlayn təhsil şagirdlər arasında ünsiyyati azaltdı̆̆ından aqressiya artır. Şagirdlərin uzun müddat evdə qalması psixoloji garginliya sabəb olur. Sputnik Azərbaycan: https://sputnik.az/news/20210313/426439258/pandemiya-dovrunde-mekteblilerle-psixoloji-ish-neceaparilir.html adresinden alındı

Ratliffe, K. T., \& Ponte, E. (2018). Parent perspectives on developing effective family-school partnerships in Hawai'i. School Community Journal, 28(1), 217-247.

Raufqız1, G. (2015, noyabr 2). Məktəblərdə valideyn komitələri ləğv edilacək. Modern.az: https://modern.az/az/news/88307/mekteblerde-valideyn-komiteleri-legv-edilecek adresinden alınd1

Şahin, M., \& Üstüner, M. (2018). Sosyal medyaya ilişkin okul yöneticilerinin görüşleri. Inonu University Journal of the Faculty of Education, 19(1), 335-355. doi:10.17679/inuefd.334250 
Stake, R. (1995). The art of case study research. Thousand Oaks, California: SAGE.

Tingley, S. (tarih yok). 7 Tips for teachers on dealing with difficult parents. WGU Hey Teach: https://www.wgu.edu/heyteach/article/7-tips-teachers-dealing-difficult-parents1804.html adresinden alındı

Topal, Ş., Erdem, E., \& Dal, H. (2013). Öğretmen adaylarına göre okul öncesi eğitimde okul-aile işbirliğinin çocuk (3666 ay) için önemi. Eğitişim Dergisi, 38, 31-40.

Topçu, S. (2018). Çocuk ve sanal ortam. Kocatepe Tıp Dergisi, 19(1), 27-33. doi:10.18229/kocatepetip.411206

Türnüklü, A., Şahin, İ., \& Öztürk, N. (2002). İlköğretim okullarında, öğrenci, öğretmen, okul yöneticisi ve velilerin çatışma çözüm stratejileri. Kuram ve Uygulamada Eğitim Yönetimi, 32(32), 574-597.

Ünal, A., Yıldırım, A., \& Çelik, M. (2010). İlköğretim okulu müdür ve öğretmenlerinin velilere ilişkin algılarının analizi. Selçuk Üniversitesi Sosyal Bilimler Enstitüsü Dergisi, 23, 261-272.

Urun, Z., \& Gökçe, A. (2015). Okul müdürlerinin baskı gruplarının istekleri ile başa çıkma taktikleri. Journal of Teacher Education and Educators, 4(1), 105 - 125.

Vahedi, M. (2010). A study of parents' participation in the high schools administration. Procedia Social and Behavioral Sciences, 2(2), 359-363. doi:https://doi.org/10.1016/j.sbspro.2010.03.025

Yıldırım, A., \& Şimşek, H. (2009). Sosyal bilimlerde nitel araştırma yöntemleri. Ankara: Seçkin Yayıncılık.

Yıldırım, M., \& Dönmez, B. (2008). Okul-aile işbirliğine ilişkin bir araştırma (İstiklal ilköğretim okulu örneği). Elektronik Sosyal Bilimler Dergisi, 7(23 ), 98-115.

Yumşak, G., \& Balc1, Ö. (2018). Öğretmenlerin istenmeyen öğrenci davranışları ile başa çıkma yöntemleri ve bu yöntemlerin etkililiğine ilişkin görüşleri. Balıkesir Üniversitesi Sosyal Bilimler Enstitüsü Dergisi, 21(40), 223254. doi:10.31795/baunsobed.489128 